\title{
Nonpeptidic Foldamers from Amino Acids: Synthesis and Characterization of 1,3-Substituted Triazole Oligomers
}

\author{
Nicholas G. Angelo and Paramjit S. Arora* \\ Department of Chemistry, New York University, New York, New York 10003
}

Supporting Information

Table of Contents:

S2 General

S2 Abbreviations

S3 Experimentals

S10 Conformational analysis

S13 NMR spectra for compound 3a (DFQ-COSY, TOCSY, ROESY, ${ }^{1} \mathrm{H}$ NMR, ${ }^{13} \mathrm{C}$ NMR)

S18 NMR spectra for compound 4a (DFQ-COSY, TOCSY, ROESY, ${ }^{1} \mathrm{H}$ NMR, ${ }^{13} \mathrm{C}$ NMR)

S23 NMR spectra for compound 3b (DFQ-COSY, TOCSY, ROESY, ${ }^{1} \mathrm{H}$ NMR, ${ }^{13} \mathrm{C}$ NMR)

S28 NMR spectra for compound $\mathbf{4 b}$ (DFQ-COSY, TOCSY, ROESY, ${ }^{1} \mathrm{H}$ NMR, ${ }^{13} \mathrm{C}$ NMR) 
General: Commercial-grade reagents and solvents were used without further purification except as indicated. DCM, THF, and DMF were dried prior to use by percolation through anhydrous $\mathrm{Al}_{2} \mathrm{O}_{3}$ as described by Grubbs and coworkers. ${ }^{1}$ All reactions were stirred magnetically; moisture-sensitive reactions were performed under nitrogen in flame-dried glassware. Unless indicated, all reactions were performed at room temperature. Thin-layer chromatography (TLC), using ethyl acetate: hexane, ethyl acetate: DCM or methanol: DCM as the solvent system, was used to monitor reactions. Visualization was accomplished by either ultraviolet light or by immersing the plate in a $1 \%$ aqueous solution of potassium permanganate and heating. Flash chromatography with silica gel was performed following the conditions described by Still and coworkers. ${ }^{2}$ Solvents were removed by rotary evaporation under reduced pressure; where appropriate, the residue was further dried using a vacuum pump. Proton NMR spectra were obtained on a Bruker AV-400 (400 MHz) spectrometer. Carbon NMR spectra were obtained on a Bruker $(100 \mathrm{MHz})$ spectrometer. Proton chemical shifts are reported as $\mathrm{d}$ values relative to tetramethylsilane $(0.00 \mathrm{ppm})$ or to the particular solvent used in the experiment. Carbon chemical shifts are reported as d values relative to the particular solvent used in the experiment $\left(\mathrm{CDCl}_{3}: 77.0 \mathrm{ppm}\right)$. Data is reported as follows: chemical shift, multiplicity $(\mathrm{s}=$ singlet, $\mathrm{d}=$ doublet, $\mathrm{t}=$ triplet, $\mathrm{q}=$ quartet, $\mathrm{m}=$ multiplet, $\mathrm{dd}=$ doublet of doublet, $\mathrm{br}=$ broad), coupling constant, and integration. Infrared (IR) spectra were obtained with a Thermo Nicolet Avatar 360 FTIR. High-resolution mass spectra (HRMS) were obtained on a LC/MSD TOF (Agilent Technologies). LRMS data was obtained on an Agilent 1100 series LC/MSD (XCT) electrospray trap.

Abbreviations: $\mathrm{DCM}=$ dichloromethane, $\mathrm{THF}=$ tetrahydrofuran, DIPEA $=\mathrm{N}, \mathrm{N}$-diisopropyl ethylamine, TFA = trifluoroacetic acid, HBTU $=N, N, N^{\prime}, N^{\prime}$-tetramethyl- $O-(1 H$-benzotriazol-1-

1 Pangborn, A. B.; Giardello, M. A.; Grubbs, R. A.; Rosen, R. K.; Timmers, F. J. Organometallics 1996, 15, 1518-1520.

${ }^{2}$ Still, W. C.; Kahn, M.; Mitra, A. J. Org. Chem. 1978, 43, 2923-2925. 
yl)uronium hexafluorophosphate, TEA $=$ triethylamine, TBTA $^{3}=$ tris-(1-benzyl-1H[1,2,3]triazol-4-ylmethyl)-amine

\section{Experimental:}

Scheme S1. Synthesis of alkynes $1 \mathrm{a}$ and $\mathbf{1 b}$. The alkynes were prepared from the aminoaldehydes by the CoreyFuchs Homologation reaction as described in references 4 and 5.

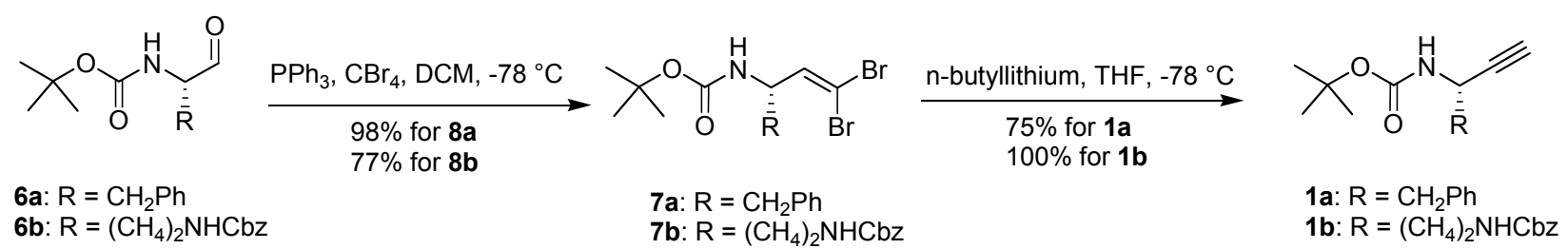

\section{Alkyne 1a. ${ }^{4}$}

${ }^{1} \mathrm{H}$ NMR (400 MHz, $\mathrm{CDCl}_{3}$ ) $\delta$ 7.25-7.15 (m, 5H), 4.68 (br s, 1H), 4.60 (br s, 1H), 2.91 (dd, AB pattern, $J=13.2,5.4 \mathrm{~Hz}, 1 \mathrm{H}), 2.86(\mathrm{dd}, \mathrm{AB}$ pattern, $J=13.3,7.1 \mathrm{~Hz}, 1 \mathrm{H}), 2.19(\mathrm{~d}, J=2.2,1 \mathrm{H})$, 1.35 (s, 9H); ${ }^{13} \mathrm{C}$ NMR (100 MHz, $\left.\mathrm{CDCl}_{3}\right) \delta 154.62,136.37,129.81,128.59,126.91,82.82$, 80.01, 72.21, 43.88, 41.73, 28.35; LRMS $m / z$ for $\mathrm{C}_{15} \mathrm{H}_{19} \mathrm{NO}_{2}[\mathrm{M}+\mathrm{Na}]^{+}$, calcd 268.1, found 268.1.

\section{Alkyne 1b. ${ }^{5}$}

${ }^{1} \mathrm{H}$ NMR (400 MHz, $\mathrm{CDCl}_{3}$ ) $\delta$ 7.23-7.17 (m, 5H), 5.22 (br t, 1H), 5.03 (br t, 1H), 5.01 (s, 2H), 4.28 (br q, 1H), 3.05 (br q, 2H), 2.19 (d, $J=2.3 \mathrm{~Hz}, 1 \mathrm{H}), 1.56-1.49$ (m, 2H), 1.41-1.35 (m, 2H), 1.34 (s, 9H), 1.33-1.17 (m, 2H); ${ }^{13} \mathrm{C}$ NMR (100 MHz, $\left.\mathrm{CDCl}_{3}\right) \delta 156.57,154.98,136.73,128.44$, 127.02, 127.98, 83.54, 79.74, 71.18, 66.43, 40.74, 35.55, 30.33, 29.31, 28.42, 22.66; LRMS m/z for $\mathrm{C}_{20} \mathrm{H}_{28} \mathrm{~N}_{2} \mathrm{O}_{4}[\mathrm{M}+\mathrm{Na}]^{+}$, calcd 383.2, found 383.2.

\footnotetext{
${ }^{3}$ Chan, R. C.; Hilgraf, R.; Sharpless, K. B.; Fokin, V. V. Org. Lett. 2004, 6, 2853-2855.

${ }^{4}$ Reginato, G.; Mordini, A.; Messina, F., Degl'Innocenti, A.; Poli, G. Tetrahedron. 1996, 52, 10985-10996.

${ }^{5}$ Hauske, J. R.; Dorff, P.; Julin, S.; Martinelli, G.; Bussolari, J. Tetrahedron Lett. 1992, 33, 3715-3716.
} 
Scheme S2. Synthesis of oligomers
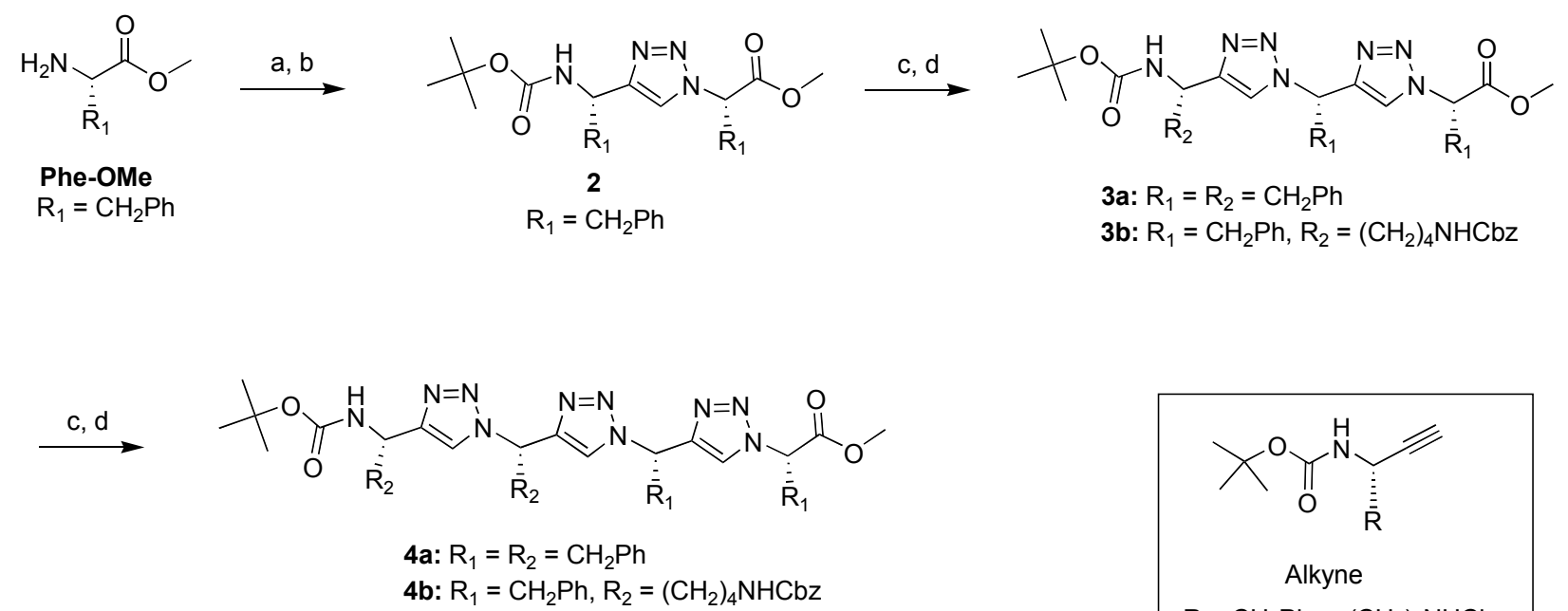

a: $\mathrm{TfN}_{3}, \mathrm{DCM}, \mathrm{CuSO}_{4}, \mathrm{TEA}$

b: Alkyne, $\mathrm{CuSO}_{4}-\mathrm{H}_{2} \mathrm{O}$, Sodium L-Ascorbate, TBTA

c: i. $30 \%-50 \%$ TFA in DCM, ii. $\mathrm{TfN}_{3}, \mathrm{DCM}, \mathrm{CuSO}_{4}, \mathrm{TEA}$

d: Alkyne, $\mathrm{CuSO}_{4}-\mathrm{H}_{2} \mathrm{O}$, Sodium L-Ascorbate, TBTA

TBTA =

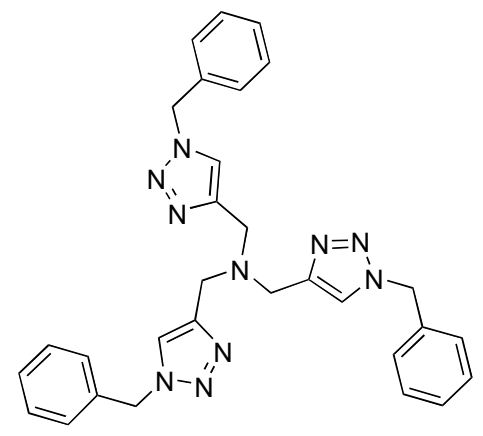

Boc dimer methyl ester (2). $\mathrm{H}-\mathrm{Phe}-\mathrm{OMe} \cdot \mathrm{HCl}(125 \mathrm{mg}, 0.580 \mathrm{mmol})$ was dissolved in a solution of triflic azide ${ }^{6}(9.30 \mathrm{mmol})$ in DCM $(25 \mathrm{~mL})$. Triethylamine $(0.33 \mathrm{~mL}, 2.32 \mathrm{mmol})$ and $\mathrm{CuSO}_{4} \cdot 5 \mathrm{H}_{2} \mathrm{O}(28 \mathrm{mg}, 0.12 \mathrm{mmol})$ were added and the reaction mixture was stirred for $16 \mathrm{~h}$. The reaction mixture was concentrated under vacuum and the residue was purified by column chromatography (DCM, 100\%) to yield azido methyl ester as a colorless oil (50 mg, 42\%). ${ }^{1} \mathrm{H}$ NMR (400 MHz, $\left.\mathrm{CDCl}_{3}\right) \delta$ 7.35-7.22 (m, 5H), 4.06 (dd, $\left.J=8.7,5.4 \mathrm{~Hz}, 1 \mathrm{H}\right), 3.77(\mathrm{~s}, 3 \mathrm{H}), 3.17$ (dd, AB pattern, $J=14.0,5.4 \mathrm{~Hz}, 1 \mathrm{H}$ ), 3.01 (dd, AB pattern, $J=14.0,8.8 \mathrm{~Hz}, 1 \mathrm{H}$ ); IR (film) $2104,1741 \mathrm{~cm}^{-1}$.

${ }^{6}$ Alper, P. B.; Hung, S-C.; Wong, C-H.; Tetrahedron Lett. 1996, 37, 6029-6032. 
To a solution of azido methyl ester $(50 \mathrm{mg}, 0.25 \mathrm{mmol})$ and alkyne $1 \mathbf{a}(181 \mathrm{mg}, 0.740 \mathrm{mmol})$ in tert-butanol $(2 \mathrm{~mL})$ was added a solution of $\mathrm{CuSO}_{4} \cdot 5 \mathrm{H}_{2} \mathrm{O}(184 \mathrm{mg}, 0.740 \mathrm{mmol})$ and TBTA (391 mg, $0.740 \mathrm{mmol})$ in 2:1 tert-butanol: water $(30 \mathrm{~mL})$. Sodium L-ascorbate $(292 \mathrm{mg}, 1.47$ mmol) was added and the reaction mixture was stirred for $16 \mathrm{~h}$. Brine $(30 \mathrm{~mL})$ was added and the mixture was extracted with DCM (3 X $30 \mathrm{~mL})$. The combined organic layers were dried over $\mathrm{MgSO}_{4}$, filtered, and concentrated under vacuum to afford a yellow oil. The oil was purified by column chromatography (ethyl acetate: DCM, 5:95) to yield Boc dimer methyl ester 2 as a white solid (84 mg, 76\%). ${ }^{1} \mathrm{H}$ NMR (400 MHz, $\mathrm{CDCl}_{3}$ ) $\delta$ 7.40-7.13 (m, 7H), 7.03-6.97 (m, 4H), 5.45 (t, $J=7.4 \mathrm{~Hz}, 1 \mathrm{H}), 5.29$ (s br, 1H), 5.03 (q, $J=7.1 \mathrm{~Hz}, 1 \mathrm{H}), 3.71$ (s, 3H), 3.46 (dd, $J=14.1,6.2 \mathrm{~Hz}$, $1 \mathrm{H}), 3.40$ (dd, AB pattern, $J=14.1,8.9 \mathrm{~Hz}, 1 \mathrm{H}), 3.28-3.25$ (m br, 1H), 3.10-3.06 (m br, $1 \mathrm{H})$, $1.41(\mathrm{~s}, 9 \mathrm{H}) ;{ }^{13} \mathrm{C}$ NMR $\left(100 \mathrm{MHz}, \mathrm{CDCl}_{3}\right) \delta 185.05,168.45,155.12,147.48,137.26,134.80$ $129.58,128.87,128.78,128.26,127.52$, 126.48, 121.39, 79.60, 64.03, 53.03, 48.69, 41.73, 38.59, 28.34; HRMS $m / z$ for $\mathrm{C}_{25} \mathrm{H}_{31} \mathrm{~N}_{4} \mathrm{O}_{4}[\mathrm{M}+\mathrm{H}]^{+}$, calcd 451.2339, found 451.2333.

Boc trimer methyl ester (3a). Boc dimer methyl ester 2 (84 mg, $0.19 \mathrm{mmol}$ ) was dissolved in a $30 \%$ TFA solution in DCM. The reaction mixture was stirred for $1 \mathrm{~h}$, dried under vacuum then redissolved in a 5\% DIPEA solution in DCM. The reaction mixture was dried under vacuum and the residue was dissolved in a solution of triflic azide $(2.98 \mathrm{mmol})$ in DCM $(8 \mathrm{~mL})$. Triethylamine $(0.10 \mathrm{~mL}, 0.75 \mathrm{mmol})$ and $\mathrm{CuSO}_{4} \bullet 5 \mathrm{H}_{2} \mathrm{O}(9 \mathrm{mg}, 0.04 \mathrm{mmol})$ were added and the reaction mixture was stirred for $16 \mathrm{~h}$. The reaction mixture was concentrated under vacuum and the residue was purified by column chromatography (DCM, 100\%) to yield azido dimer methyl ester as a colorless oil (56 mg, 79\%). ${ }^{1} \mathrm{H}$ NMR (400 MHz, $\left.\mathrm{CDCl}_{3}\right) \delta 7.47(\mathrm{~s}, 1 \mathrm{H}), 7.28-7.22(\mathrm{~m}$, $6 \mathrm{H}), 7.19-7.16(\mathrm{~m}, 2 \mathrm{H}), 6.98-6.96(\mathrm{~m}, 2 \mathrm{H}), 5.57(\mathrm{dd}, J=8.7,6.1 \mathrm{~Hz}, 1 \mathrm{H}), 4.86(\mathrm{dd}, J=8.4,5.7$ $\mathrm{Hz}, 1 \mathrm{H}), 3.76(\mathrm{~s}, 3 \mathrm{H}), 3.51-3.43(\mathrm{~m}, 2 \mathrm{H}), 3.27$ (dd, AB pattern, $J=13.9,5.8 \mathrm{~Hz}, 1 \mathrm{H}), 3.13(\mathrm{dd}, J$ $=17.2,8.4 \mathrm{~Hz}, 0.5 \mathrm{H}), 3.07(\mathrm{dd}, J=17.1,8.4 \mathrm{~Hz}, 0.5 \mathrm{H})$; IR (film) $2090,1730 \mathrm{~cm}^{-1}$.

To a solution of azido dimer methyl ester $(56 \mathrm{mg}, 0.15 \mathrm{mmol})$ and alkyne $1 \mathrm{a}(109 \mathrm{mg}, 0.444$ $\mathrm{mmol})$ in DMF (2 mL) was added a solution of TBTA $(176 \mathrm{mg}, 0.888 \mathrm{mmol})$ in DMF (8 mL). A solution of $\mathrm{CuSO}_{4} \cdot 5 \mathrm{H}_{2} \mathrm{O}(111 \mathrm{mg}, 0.444 \mathrm{mmol})$ in water $(1 \mathrm{~mL})$ and a solution of sodium Lascorbate $(176 \mathrm{mg}, 0.888 \mathrm{mmol})$ in water $(1 \mathrm{~mL})$ were then added and the reaction mixture was stirred for $16 \mathrm{~h}$. Brine $(10 \mathrm{~mL})$ was added and the mixture was extracted with DCM (3 X 10 
$\mathrm{mL}$ ). The combined organic layers were dried over $\mathrm{MgSO}_{4}$, filtered, and concentrated under vacuum to afford a yellow oil. The oil was purified by column chromatography (ethyl acetate: hexanes, 1:1) to yield Boc trimer methyl ester 3a as a white solid (41 mg, 45\%). ${ }^{1} \mathrm{H}$ NMR (400 MHz, d6-DMSO) $\delta 8.34$ (s, 1H), 7.90 (s, 1H), 7.26-7.20 (m, 3H), 7.19-7.13 (m, 8H), 7.12-7.07 $(\mathrm{m}, 2 \mathrm{H}), 7.06-7.00(\mathrm{~m}, 2 \mathrm{H}), 6.18(\mathrm{t}, J=7.8 \mathrm{~Hz}, 1 \mathrm{H}), 5.82(\mathrm{dd}, J=10.6,5.2 \mathrm{~Hz}, 1 \mathrm{H}), 4.82(\mathrm{q}, J=$ $8.8 \mathrm{~Hz}, 1 \mathrm{H}), 3.69$ (s, 3H), 3.57-3.50 (m, 3H), 3.43 (dd, $J=14.1,10.7 \mathrm{~Hz}, 1 \mathrm{H}), 3.07$ (dd, AB pattern, $J=13.6,5.6 \mathrm{~Hz}, 1 \mathrm{H}), 2.94(\mathrm{dd}, \mathrm{AB}$ pattern, $J=13.7,9.4 \mathrm{~Hz}, 1 \mathrm{H}), 1.29(\mathrm{~s}, 9 \mathrm{H}) ;{ }^{13} \mathrm{C}$ NMR (100 MHz, d6-DMSO) $\delta 168.43,154.80,148.79,144.86,138.26,136.39,135.50,129.11$, $128.95,128.72,128.20,128.09,127.87,126.75,126.52,125.93,123.80,120.84,77.67,63.10$, 57.38, 52.80, 48.44, 40.50, 36.65, 28.07; HRMS $m / z$ for $\mathrm{C}_{35} \mathrm{H}_{40} \mathrm{~N}_{7} \mathrm{O}_{4}[\mathrm{M}+\mathrm{H}]^{+}$, calcd 622.3136, found 622.3132 .

Boc tetramer methyl ester (4a). Boc trimer methyl ester 3a (41 mg, $0.066 \mathrm{mmol})$ was dissolved in a 50\% TFA solution in DCM. The reaction mixture was stirred for $1 \mathrm{~h}$, dried under vacuum then redissolved in a 5\% DIPEA solution in DCM. The reaction mixture was dried under vacuum and the residue was dissolved in a solution of triflic azide $(1.06 \mathrm{mmol})$ in DCM $(3 \mathrm{~mL})$. Triethylamine $(0.037 \mathrm{~mL}, 0.27 \mathrm{mmol})$ and $\mathrm{CuSO}_{4} \bullet 5 \mathrm{H}_{2} \mathrm{O}(3 \mathrm{mg}, 0.01 \mathrm{mmol})$ were added and the reaction mixture was stirred for $16 \mathrm{~h}$. The reaction mixture was dried under vacuum and the residue was purified by column chromatography (ethyl acetate: DCM, 10:90) to yield azido trimer methyl ester as a colorless oil (28 mg, 76\%). ${ }^{1} \mathrm{H}$ NMR (400 MHz, $\left.\mathrm{CDCl}_{3}\right) \delta 7.56(\mathrm{~s}, 0.5 \mathrm{H})$, $7.54(\mathrm{~s}, 0.5 \mathrm{H}), 7.44(\mathrm{~s}, 0.5 \mathrm{H}), 7.43(\mathrm{~s}, 0.5 \mathrm{H}), 7.41-7.13(\mathrm{~m}, 11 \mathrm{H}), 6.99-6.88(\mathrm{~m}, 4 \mathrm{H}), 6.09$ (br s, 1H), 5.99-5.94 (m, 1H), 5.55 (dd, $J=8.5,7.2 \mathrm{~Hz}, 1 \mathrm{H}), 4.86-4.81(\mathrm{~m}, 1 \mathrm{H}), 3.75(\mathrm{~s}, 3 \mathrm{H}), 3.61-3.52$ (m, 2H), 3.50-3.46 (m, 1H), 3.44-3.36 (m, 1H), $3.25(\mathrm{dd}$, AB pattern, $J=13.9,5.7 \mathrm{~Hz}, 1 \mathrm{H}), 3.10$ (dd, AB pattern, $J=13.8,8.6 \mathrm{~Hz}, 1 \mathrm{H}$ ) ; IR (film) $2100,1750 \mathrm{~cm}^{-1}$.

To a solution of azido trimer methyl ester $(28 \mathrm{mg}, 0.050 \mathrm{mmol})$ and alkyne 1a $(74 \mathrm{mg}, 0.30$ mmol) in DMF (2 mL) was added a solution of TBTA (160 mg, $0.30 \mathrm{mmol})$ in DMF (8 mL). A solution of $\mathrm{CuSO}_{4} \cdot 5 \mathrm{H}_{2} \mathrm{O}(76 \mathrm{mg}, 0.30 \mathrm{mmol})$ in water $(1 \mathrm{~mL})$ and a solution of sodium Lascorbate $(120 \mathrm{mg}, 0.60 \mathrm{mmol})$ in water $(1 \mathrm{~mL})$ were added and the reaction mixture was stirred for $16 \mathrm{~h}$. Brine $(5 \mathrm{~mL})$ was added and the mixture was extracted with DCM $(3 \times 5 \mathrm{~mL})$. The combined organic layers were dried over $\mathrm{MgSO}_{4}$, filtered, and dried under vacuum to afford a 
yellow oil. The oil was purified by column chromatography (ethyl acetate: hexanes, 1:1) to yield Boc tetramer methyl ester $4 \mathbf{a}$ as a white solid (30 mg, 75\%). ${ }^{1} \mathrm{H}$ NMR (400 MHz, d6-Acetone) $\delta 7.97(\mathrm{~s}, 1 \mathrm{H}), 7.84(\mathrm{~s}, 0.3 \mathrm{H}), 7.82(\mathrm{~s}, 0.7 \mathrm{H}), 7.60$ (br s, 1H), 7.10-7.06 (m, 16H), 7.04-6.96 (m, $1 \mathrm{H}), 6.95-6.92(\mathrm{~m}, 3 \mathrm{H}), 6.12-6.09$ (br d, $J=8.4 \mathrm{~Hz}, 1 \mathrm{H}), 6.03(\mathrm{t}, J=7.7 \mathrm{~Hz}, 1 \mathrm{H}), 5.98(\mathrm{t}, J=8.0$ Hz, 1H), 5.62-5.58 (dd, $J=10.1,5.4 \mathrm{~Hz}, 1 \mathrm{H}), 4.89$ (q, $J=7.8 \mathrm{~Hz}, 1 \mathrm{H}), 3.60$ (s, 3H), 3.49-3.47 (m, 5H), $3.37(\mathrm{dd}, J=10.2,7.1 \mathrm{~Hz}, 1 \mathrm{H}), 3.05(\mathrm{dd}, \mathrm{AB}$ pattern, $J=13.5,6.3 \mathrm{~Hz}, 1 \mathrm{H}), 2.96(\mathrm{dd}$, AB pattern, $J=13.4,8.0 \mathrm{~Hz}, 1 \mathrm{H}), 1.20(\mathrm{~s}, 9 \mathrm{H}) ;{ }^{13} \mathrm{C} \mathrm{NMR}\left(100 \mathrm{MHz}, \mathrm{CDCl}_{3}\right) \delta 168.24,155.05$, $144.95,144.59$, 144.37, 137.33, 136.03, 135.67, 135.62, 134.36, 134.29, 129.55, 129.04, 129.02, $128.93,128.87,128.83,128.64,128.59,128.24,127.70,127.26,127.13,126.46,123.13,122.85$, 122.28, 120.94, 79.54, 64.18, 64.14, 59.39, 59.08, 53.18, 53.15, 48.71, 42.23, 41,96, 41.62, 39.04, 38.81, 28.35; HRMS $m / z$ for $\mathrm{C}_{45} \mathrm{H}_{48} \mathrm{~N}_{10} \mathrm{O}_{4}[\mathrm{M}+\mathrm{H}]^{+}$, calcd 793.3932, found 793.3953.

Boc trimer methyl ester (3b). Boc dimer methyl ester 2 (89 mg, $0.20 \mathrm{mmol})$ was dissolved in a $30 \%$ TFA solution in DCM. The reaction mixture was stirred for $1 \mathrm{~h}$, dried under vacuum then redissolved in a 5\% DIPEA solution in DCM. The reaction mixture was dried under vacuum and the residue was dissolved in a solution of triflic azide $(2.98 \mathrm{mmol})$ in DCM $(8 \mathrm{~mL})$. Triethylamine $(0.10 \mathrm{~mL}, 0.75 \mathrm{mmol})$ and $\mathrm{CuSO}_{4} \cdot 5 \mathrm{H}_{2} \mathrm{O}(9 \mathrm{mg}, 0.04 \mathrm{mmol})$ were added and the reaction mixture was stirred for $16 \mathrm{~h}$. The reaction mixture was concentrated under vacuum and the residue was purified by column chromatography (DCM, 100\%) to yield azido dimer methyl ester as a colorless oil (56 mg, 79\%). ${ }^{1} \mathrm{H}$ NMR (400 MHz, $\left.\mathrm{CDCl}_{3}\right) \delta 7.47(\mathrm{~s}, 1 \mathrm{H}), 7.28-7.22(\mathrm{~m}$, $6 \mathrm{H}), 7.19-7.16(\mathrm{~m}, 2 \mathrm{H}), 6.98-6.96(\mathrm{~m}, 2 \mathrm{H}), 5.57(\mathrm{dd}, J=8.7,6.1 \mathrm{~Hz}, 1 \mathrm{H}), 4.86(\mathrm{dd}, J=8.4,5.7$ $\mathrm{Hz}, 1 \mathrm{H}), 3.76$ (s, 3H), 3.51-3.43 (m, 2H), 3.27 (dd, AB pattern, $J=13.9,5.8 \mathrm{~Hz}, 1 \mathrm{H}), 3.13$ (dd, $J$ $=17.2,8.4 \mathrm{~Hz}, 0.5 \mathrm{H}), 3.07(\mathrm{dd}, J=17.1,8.4 \mathrm{~Hz}, 0.5 \mathrm{H})$; IR (film) $2090,1730 \mathrm{~cm}^{-1}$.

To a solution of azido dimer methyl ester (54 mg, $0.14 \mathrm{mmol})$ and alkyne 1 b (104 mg, 0.29 mmol) in tert-butanol (20 mL) was added TBTA (154 mg, $0.29 \mathrm{mmol})$. A solution of $\mathrm{CuSO}_{4} \bullet$ $5 \mathrm{H}_{2} \mathrm{O}(36 \mathrm{mg}, 0.15 \mathrm{mmol})$ in water $(5 \mathrm{~mL})$ and a solution of sodium L-ascorbate $(57 \mathrm{mg}, 0.29$ $\mathrm{mmol})$ in water $(5 \mathrm{~mL})$ were then added and the reaction mixture was stirred for $48 \mathrm{~h}$. Brine (20 $\mathrm{mL})$ was added and the mixture was extracted with DCM (3 X $20 \mathrm{~mL})$. The combined organic layers were dried over $\mathrm{MgSO}_{4}$, filtered, and concentrated under vacuum to afford a yellow oil. The oil was purified by column chromatography (methanol: ethyl acetate, 1:20) to yield Boc 
trimer methyl ester $\mathbf{3 b}$ as a white solid (100.3 mg, 94\%). ${ }^{1} \mathrm{H}$ NMR (400 MHz, d6-Acetone) $\delta 8.08(\mathrm{~s}, 1 \mathrm{H}), 7.77(\mathrm{~s}, 1 \mathrm{H}), 7.36-7.28(\mathrm{~m}, 4 \mathrm{H}), 7.22-7.17(\mathrm{~m}, 7 \mathrm{H}), 7.16-7.05(\mathrm{~m}, 4 \mathrm{H}), 6.31$ (br s, $1 \mathrm{H}), 6.19-6.17(\mathrm{~d}, J=8.4 \mathrm{~Hz}, 1 \mathrm{H}), 6.13(\mathrm{t}, J=7.9 \mathrm{~Hz}, 1 \mathrm{H}), 5.72(\mathrm{dd}, J=10.1,5.5 \mathrm{~Hz}, 1 \mathrm{H}), 5.05$ $(\mathrm{s}, 2 \mathrm{H}), 4.76(\mathrm{q}, J=7.0 \mathrm{~Hz}, 1 \mathrm{H}), 3.72(\mathrm{~s}, 3 \mathrm{H}), 3.63-3.58(\mathrm{~m}, 3 \mathrm{H}), 3.51$ (dd, AB pattern, $J=14.2$, $10.1 \mathrm{~Hz}, 1 \mathrm{H}), 3.13$ (q, $J=6.9 \mathrm{~Hz}, 2 \mathrm{H}), 1.89-1.78$ (m, 2H), 1.56-1.49 (m, 2H), 1.39 (s, 9H), 1.35$1.29(\mathrm{~m}, 2 \mathrm{H}) ;{ }^{13} \mathrm{C} \mathrm{NMR}\left(100 \mathrm{MHz}, \mathrm{CDCl}_{3}\right) \delta 168.29,156.43,155.33,145.04,136.66,135.96$, $134.44,129.08,129.01,128.88,128.84,128.83,128.60,128.51,128.35,128.12,128.07,127.67$, $127.16,122.87,120.93,79.59$, 66.59, 64.17, 59.20, 53.16, 46.82, 42.10, 40.77, 38.76, 35.69, 35.16, 29.41, 28.38, 22.79; HRMS $m / z$ for $\mathrm{C}_{40} \mathrm{H}_{49} \mathrm{~N}_{8} \mathrm{O}_{6}[\mathrm{M}+\mathrm{H}]^{+}$, calcd 737.3769, found 737.3760.

Boc tetramer methyl ester (4b). Boc trimer methyl ester 3b (49 mg, $0.070 \mathrm{mmol}$ ) was dissolved in a 50\% TFA solution in DCM. The reaction mixture was stirred for $1 \mathrm{~h}$, concentrated under vacuum then redissolved in a 5\% DIPEA solution in DCM. The reaction mixture was concentrated under vacuum and the residue was dissolved in a solution of triflic azide (1.06 $\mathrm{mmol})$ in DCM $(2.2 \mathrm{~mL})$. Triethylamine $(0.037 \mathrm{~mL}, 0.27 \mathrm{mmol})$ and $\mathrm{CuSO}_{4}(2 \mathrm{mg}, 0.01 \mathrm{mmol})$ were added and the reaction mixture was stirred for $16 \mathrm{~h}$. The reaction mixture was dried under vacuum and the residue was purified by column chromatography (ethyl acetate: DCM, 10:90) to yield azido trimer methyl ester as a colorless oil $(47.5 \mathrm{mg}, 100 \%)$. ${ }^{1} \mathrm{H}$ NMR (400 $\left.\mathrm{MHz}, \mathrm{CDCl}_{3}\right)$ $\delta 7.56$ (br s, 1H), 7.43 (br s, 1H), 7.30-7.23 (m, 4H), 7.15-7.10 (m, 7H), 6.92-6.84 (m, 4H), 5.90 $(\mathrm{t}, J=3.0 \mathrm{~Hz}, 1 \mathrm{H}), 5.48(\mathrm{dd}, J=8.8,6.2 \mathrm{~Hz}, 1 \mathrm{H}), 5.01(\mathrm{~s}, 2 \mathrm{H}), 4.78(\mathrm{t}, J=5.6 \mathrm{~Hz}, 1 \mathrm{H}), 4.48(\mathrm{t}, J$ $=6.9 \mathrm{~Hz}, 1 \mathrm{H}), 3.68(\mathrm{~s}, 3 \mathrm{H}), 3.54(\mathrm{~d}, J=7.5 \mathrm{~Hz}, 2 \mathrm{H}), 3.43(\mathrm{dd}, \mathrm{AB}$ pattern, $J=14.2,6.2 \mathrm{~Hz}, 1 \mathrm{H})$, 3.37 (dd, AB pattern, $J=14.2,8.8 \mathrm{~Hz}, 1 \mathrm{H}), 3.12-3.06(\mathrm{~m}, 2 \mathrm{H}), 1.78(\mathrm{q}, J=7.5 \mathrm{~Hz}, 2 \mathrm{H}), 1.47-$ 1.42 (m, 2H), 1.34-1.18 (m, 2H); IR (film) 2101, $1737 \mathrm{~cm}^{-1}$.

To a solution of azido trimer methyl ester $(47.5 \mathrm{mg}, 0.070 \mathrm{mmol})$ and alkyne $1 \mathbf{b}(52 \mathrm{mg}, 0.14$ mmol) in tert-butanol $(18 \mathrm{~mL})$ was added TBTA $(74 \mathrm{mg}, 0.14 \mathrm{mmol})$. A solution of $\mathrm{CuSO}_{4} \bullet$ $5 \mathrm{H}_{2} \mathrm{O}(18 \mathrm{mg}, 0.070 \mathrm{mmol})$ in water $(2 \mathrm{~mL})$ and a solution of sodium L-ascorbate $(28 \mathrm{mg}, 0.14$ $\mathrm{mmol})$ in water $(2 \mathrm{~mL})$ were added and the reaction mixture was stirred for $16 \mathrm{~h}$. Brine $(20 \mathrm{~mL})$ was added and the mixture was extracted with DCM (3 X $20 \mathrm{~mL})$. The combined organic layers were dried over $\mathrm{MgSO}_{4}$, filtered, and concentrated under vacuum to afford a yellow oil. The oil was purified by column chromatography (methanol:ethyl acetate, 1:20) to yield Boc tetramer 
methyl ester 4b as a white solid (36.9 mg, 50\%). ${ }^{1} \mathrm{H}$ NMR (400 MHz, $d 6$-DMSO) $\delta 8.37$ (s, 1H), 8.17 (s, 1H), 7.83 (s, 1H), 7.38-7.30 (m, 9H), 7.22-7.19 (m, 2H), 7.15-7.11 (m, 5H), 7.07-7.01 $(\mathrm{m}, 4 \mathrm{H}), 6.19(\mathrm{t}, J=8.1 \mathrm{~Hz}, 1 \mathrm{H}), 5.84(\mathrm{t}, J=5.3 \mathrm{~Hz}, 1 \mathrm{H}), 5.82-5.81(\mathrm{~m}, 1 \mathrm{H}), 5.00(\mathrm{~s}, 4 \mathrm{H}), 4.68-$ 4.54 (br q, 1H), 3.69 (s, 3H), 3.56-3.52 (m, 3H), 3.45 (dd, AB pattern, $J=14.3,10.4 \mathrm{~Hz}, 1 \mathrm{H})$, 2.97-2.92 (m, 4H), $2.17(\mathrm{q}, J=7.6 \mathrm{~Hz}, 2 \mathrm{H}), 1.83-1.71(\mathrm{~m}, 1 \mathrm{H}), 1.70-1.58(\mathrm{~m}, 1 \mathrm{H}), 1.50-1.17(\mathrm{~m}$, $6 \mathrm{H}), 1.37(\mathrm{~s}, 9 \mathrm{H}), 1.16-1.05(\mathrm{~m}, 1 \mathrm{H}), 1.04-0.96(\mathrm{~m}, 1 \mathrm{H}) ;{ }^{13} \mathrm{C}$ NMR (100 MHz, d6-DMSO) $\delta 168.51,156.02,155.18,149.53,145.17,144.66,137.25,137.21,136.30,135.54,128.98$, $128.78,128.31,128.26,128.14,127.69,126.83,126.62,124.00,122.56,120.35,77.74,65.08$, $65.05,63.15,57.78,56.17,52.88,46.90,36.67,34.56,34.20,29.06,28.66,28.17,22.87,22.63$; HRMS $m / z$ for $\mathrm{C}_{55} \mathrm{H}_{67} \mathrm{~N}_{12} \mathrm{O}_{8}[\mathrm{M}+\mathrm{H}]^{+}$, calcd 1023.5199 , found 1023.5163 . 
Angelo, et al.

\section{Conformational Analysis}

The preference for anti over syn can be rationalized by considering the dipole-dipole interactions between the two neighboring triazole rings (Figure S1). The 1,2,3-triazole ring features a large dipole ( $~ 5$ Debye) that bisects the ring plane near atoms N3 and C5.

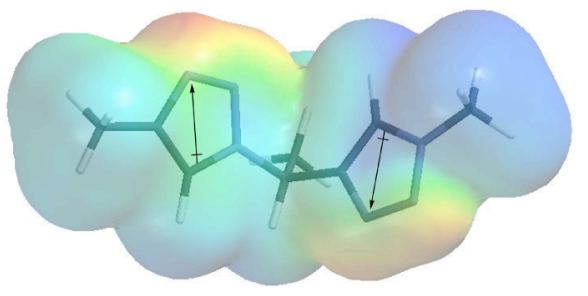

Figure S1 . Dipole-dipole interactions between adjacent triazole rings. Arrows depict dipole direction within individual triazole rings. For clarity, side chains are depicted as methyl groups.

Figure S2 shows the predicted backbone conformations for the tetramer series. As the number of rings increases, the oligomer may adopt two backbone conformations while retaining the anti geometry between adjacent triazole rings. Analysis of the ROESY spectra of the tetramers suggests that the zigzag backbone conformation is favored over the turn conformation. The major conformation of each compound is readily revealed by the intensity of ROE crosspeaks between the triazole ring protons and the adjoining $\mathrm{C}_{\alpha}$ protons (Figure $\mathrm{S} 2$ ). The turn

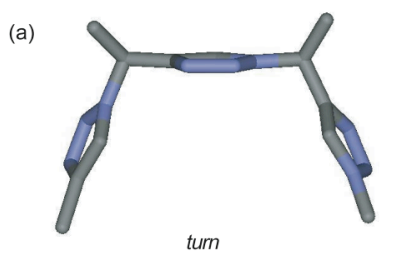

(b)

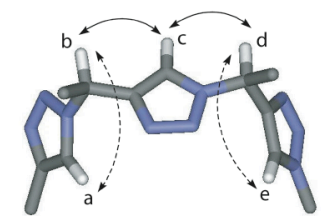

turn
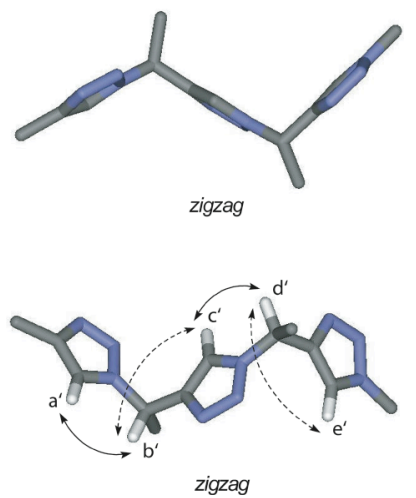

Figure S2. Tetramer 4 can adopt two distinct backbone conformations labeled turn and zigzag. (b) Predicted ROESY crosspeaks for the two conformations. Patterns and intensities of ROESY crosspeaks are expected to readily reveal the major conformation in solution. Solid and dashed lines indicate (predicted) strong and weak NOE crosspeaks, respectively. For clarity, side chains are depicted as methyl groups.

conformations would be expected to provide near-equal intensity ROE crosspeaks between the triazole ring protons (proton $\mathrm{c}$ in Figure $\mathrm{S} 2 \mathrm{~b}$ ) and adjoining the $\mathrm{C}_{\alpha}$ protons (proton $\mathrm{b}$ and $\mathrm{d}$ in Figure $\mathrm{S} 2 \mathrm{~b}$ ) because the distances between b-c and c-d protons are predicted to be similar ( $2.8 \AA$ ) in the turn conformation. Alternatively, in the zigzag conformation, the pattern and intensities of 
ROE crosspeaks between the same set of ring protons are expected to be substantially different as the distances between b'-c' and c'-d' protons in the zigzag conformation are $2.8 \AA$ and $3.9 \AA$, respectively. Examination of the 2D NMR spectra reveals that the backbones of triazolamers 3 and 4 predominantly adopt zigzag conformations in solution (Figure S3).
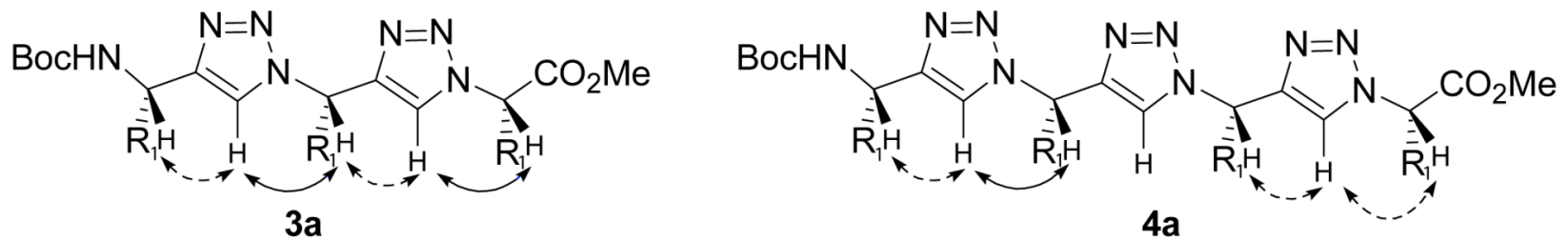

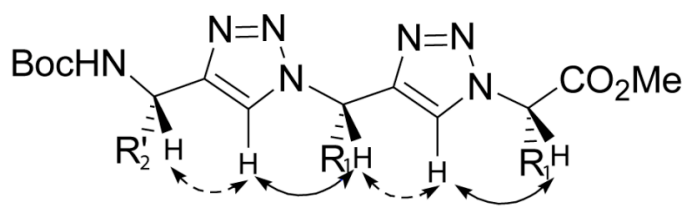

$3 \mathbf{b}$

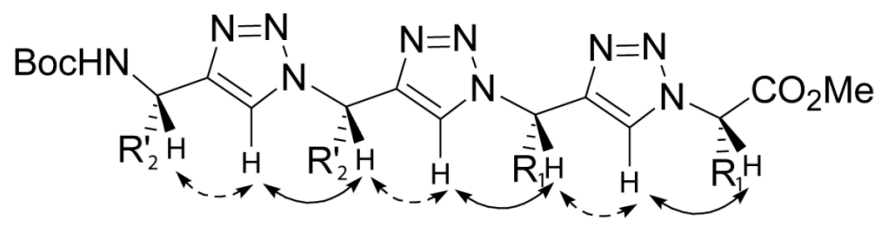

4b

$$
\mathrm{R}_{1}=\mathrm{CH}_{2} \mathrm{Ph}, \mathrm{R}_{2}=\left(\mathrm{CH}_{2}\right)_{4} \mathrm{NHCbz}
$$

Figure S3. Results of the ROESY experiments performed in $d 6$-DMSO or $d 6$-acetone for triazolamers 3 and 4 . Overlapping NMR signals precluded complete assignment for 4a. Solid and dashed lines indicate strong and weak NOE crosspeaks, respectively. 
Angelo, et al.

\section{NMR experiments}

${ }^{1}$ H NMR DFQ-COSY Experiments. DFQ-COSY studies were performed on Bruker Avance 400 spectrometer. DFQ-COSY spectra were recorded at $298 \mathrm{~K}$ with the delay for evolution of long-range correlations set to $200 \mathrm{~ms}$ and were acquired with $2 \mathrm{k}$ points in the $f 2$ domain and 256 points in the $f 1$ domain. The data were processed using Bruker XWINNMR software on an HP Workstation X1100. A $90^{\circ}$ sine-squared window function was applied in both directions. The data were zero-filled once in $f 1$ domain to give a final matrix of $1 \mathrm{k}$ by $1 \mathrm{k}$ real points.

${ }^{1}$ H NMR TOCSY Experiments. TOCSY studies were performed on Bruker Avance 400 spectrometer. TOCSY spectra were recorded at $298 \mathrm{~K}$ with a mixing time of $80 \mathrm{~ms}$ and were acquired with $2 \mathrm{k}$ points in $f 2$ domain and 256 points in $f 1$ domain. The data were processed using Bruker XWINNMR software on a HP Workstation X1100. A $90^{\circ}$ sine-squared window function was applied in both directions. The data were zero-filled to give a final matrix of $1 \mathrm{k}$ by $1 \mathrm{k}$ real points.

${ }^{1}$ H NMR ROESY Experiments. The ROESY studies were performed on Bruker Avance 400 spectrometer. The ROESY spectra were recorded at $298 \mathrm{~K}$ with a mixing time of $200 \mathrm{~ms}$ and were acquired with $2 \mathrm{k}$ points in the $f 2$ domain and 256 points in the $f 1$ domain. The data were processed using Bruker XWINNMR software on an HP Workstation X1100. A 90 sine-squared window function was applied in both directions. The data were zero-filled once in $f 1$ domain to give a final matrix of $1 \mathrm{k}$ by $1 \mathrm{k}$ real points. 
Angelo, et al.
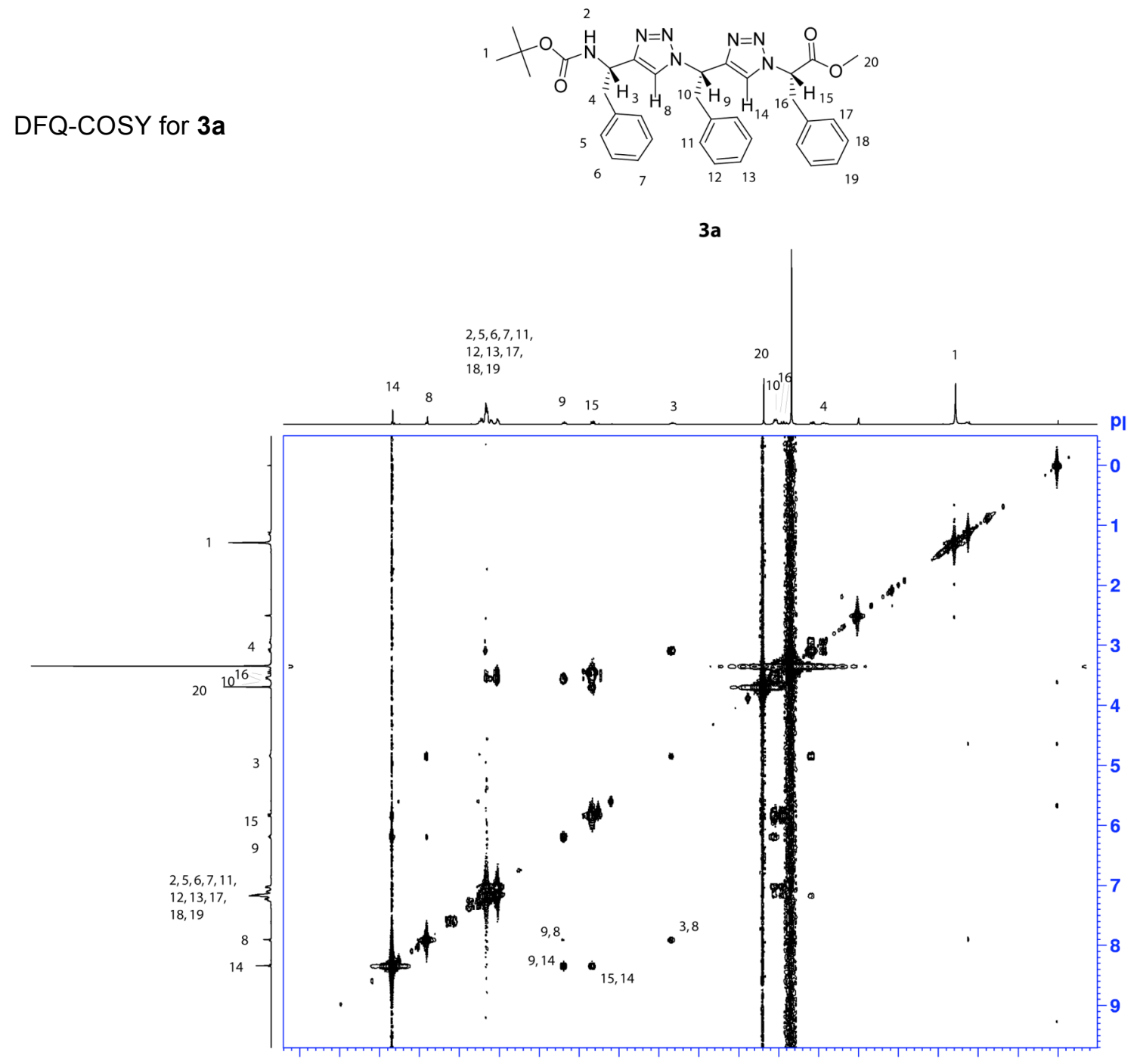
Angelo, et al.
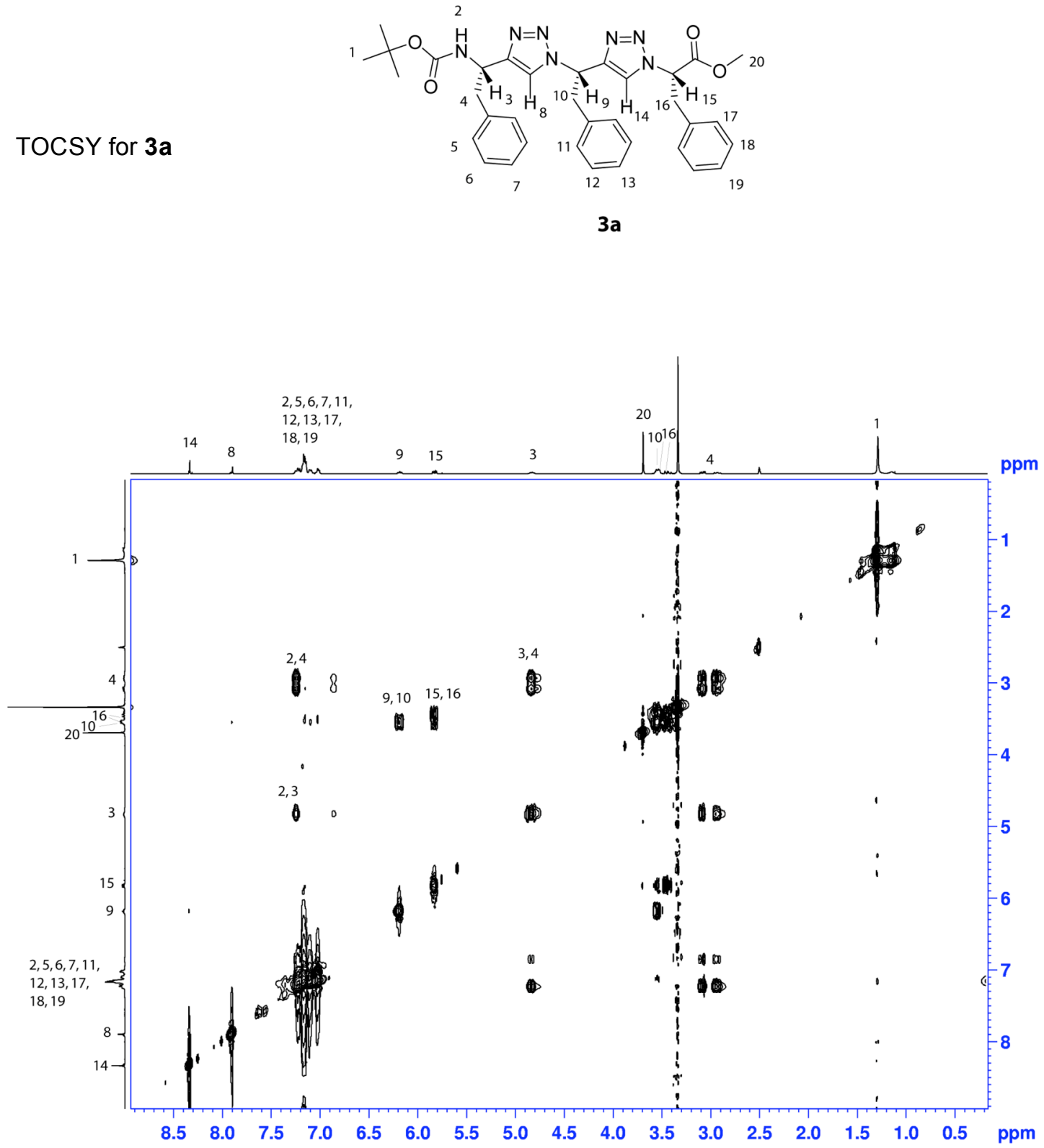
Angelo, et al.

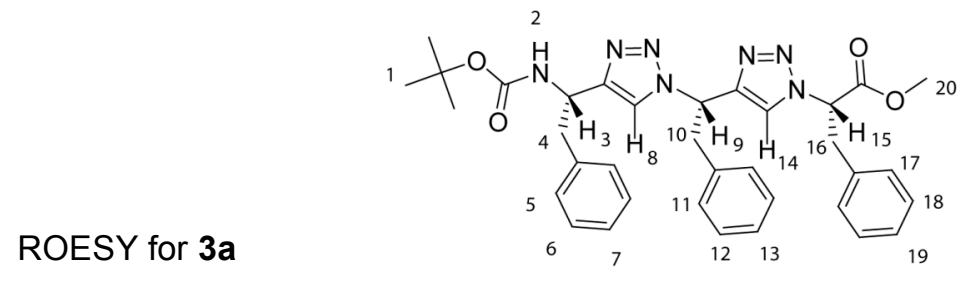

$3 a$

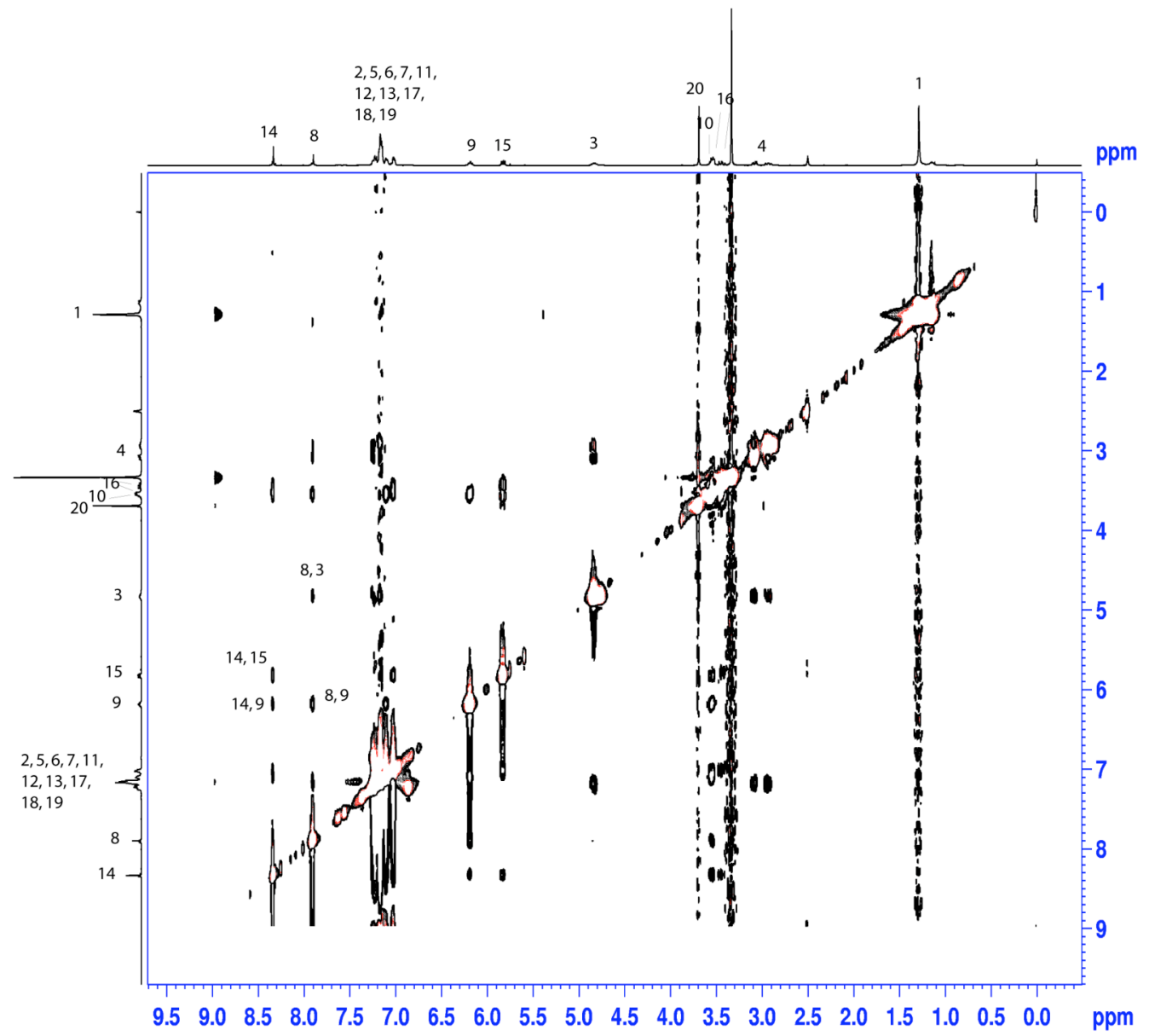


Angelo, et al.

${ }^{1} \mathrm{H}$ NMR for $\mathbf{3 a}$

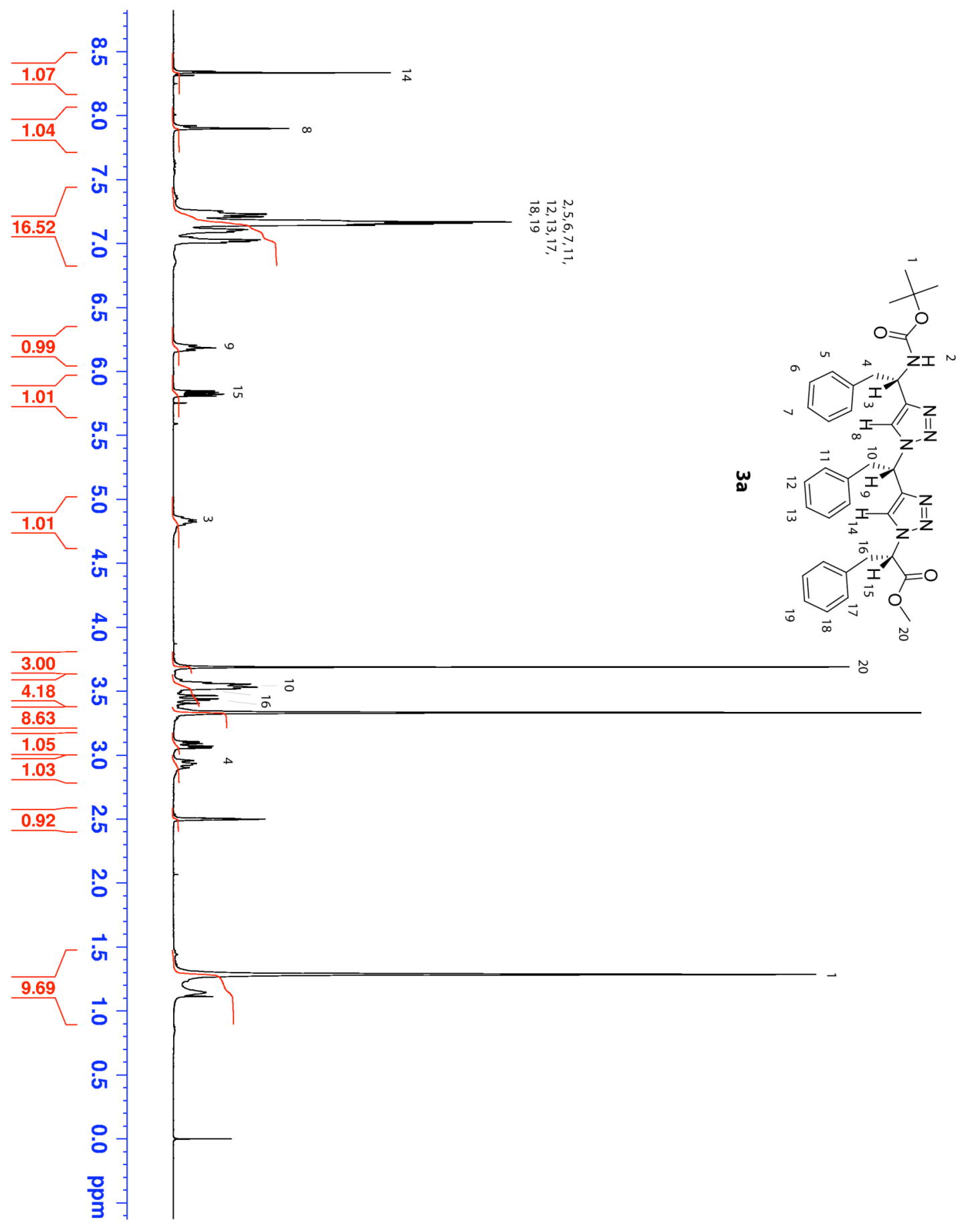


Angelo, et al.

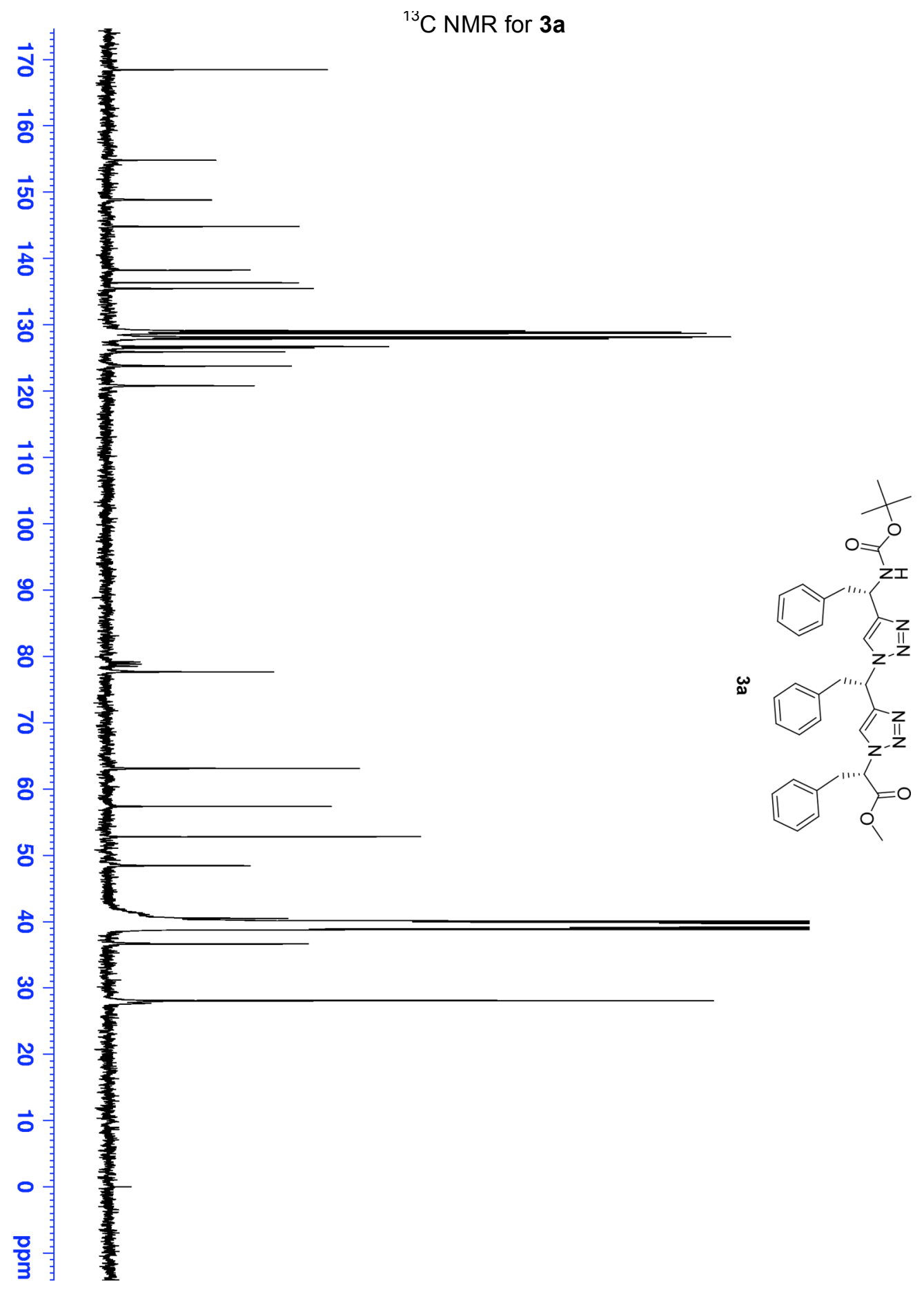


Angelo, et al.

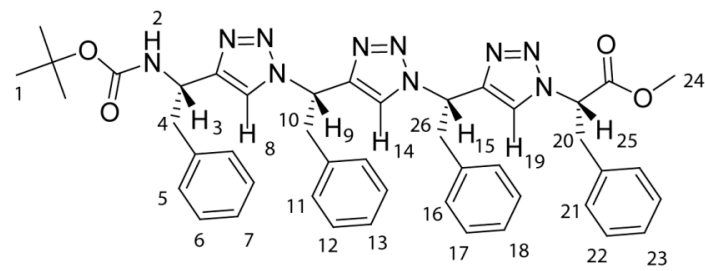

DFQ-COSY for $4 a$

$4 a$

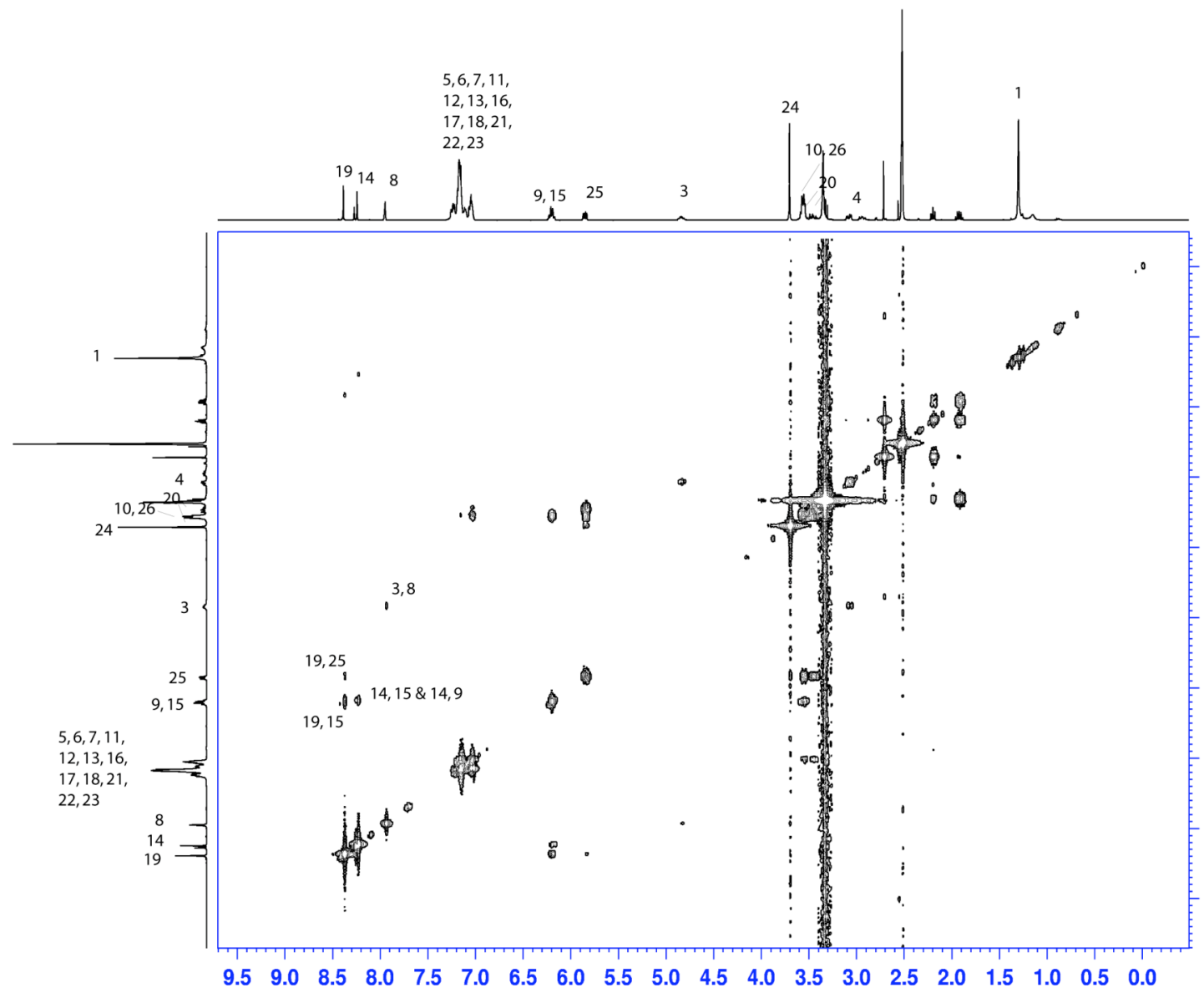


Angelo, et al.
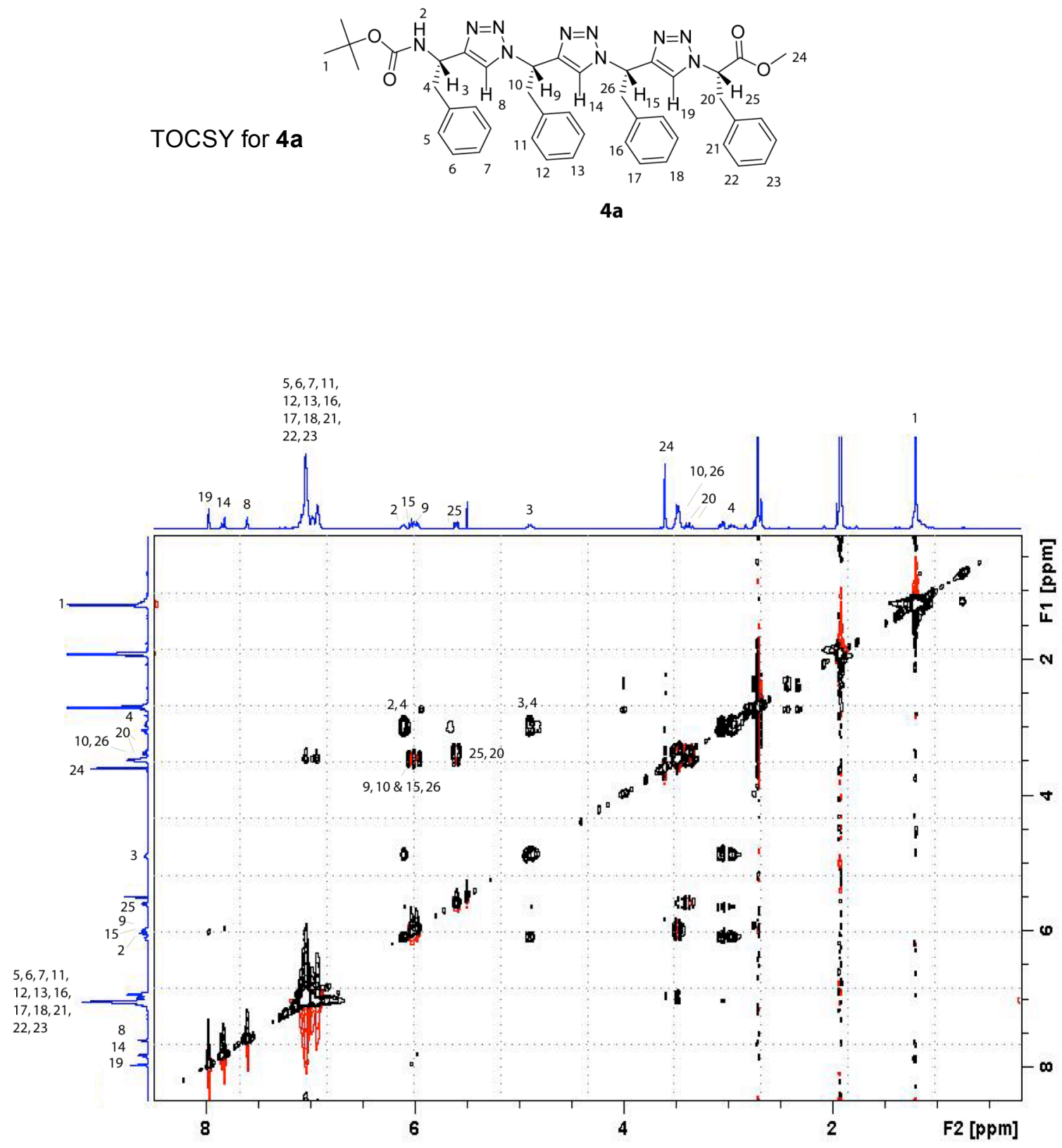
Angelo, et al.
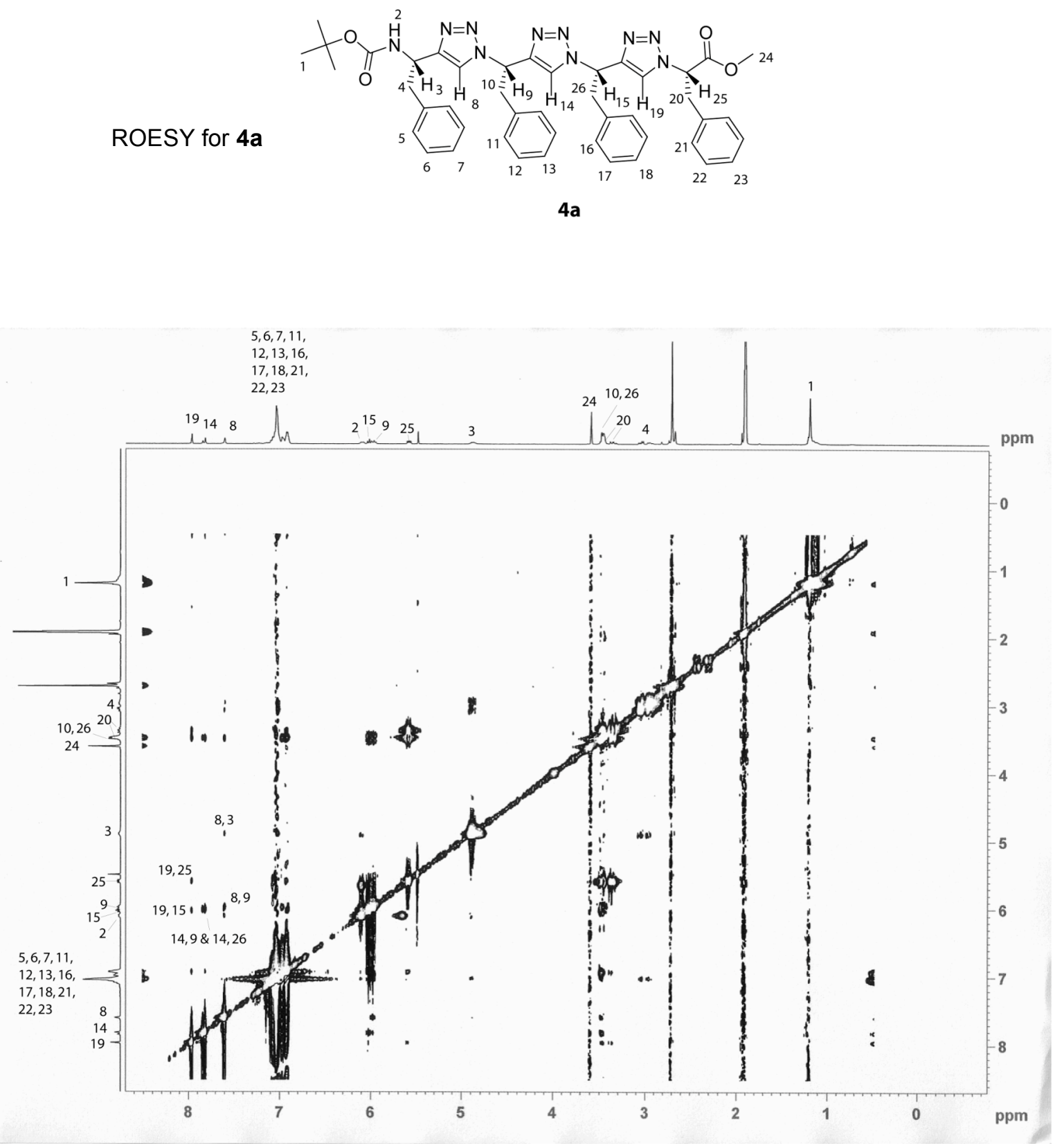
Angelo, et al.

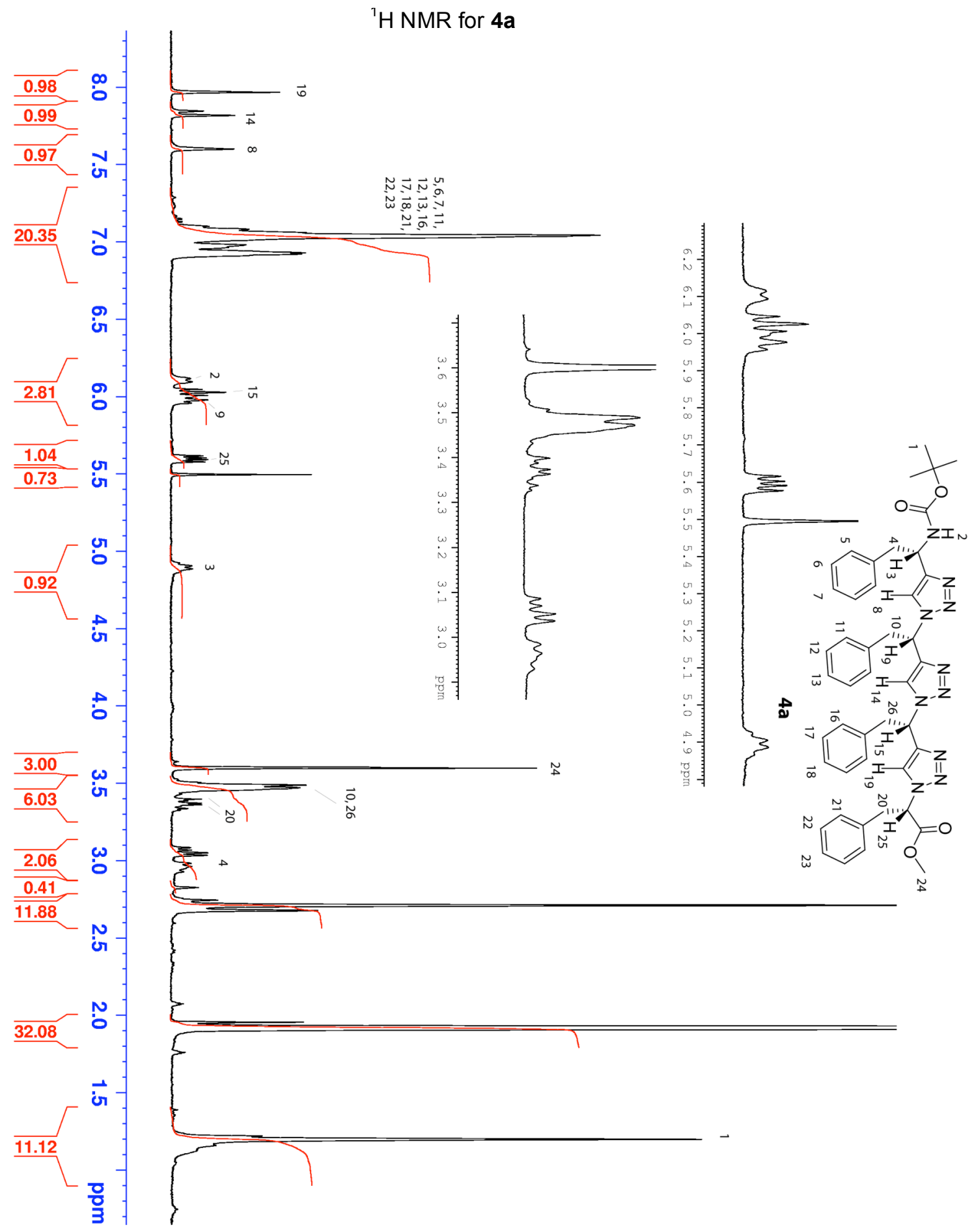


Angelo, et al.

${ }^{73} \mathrm{C}$ NMR for $4 \mathbf{a}$

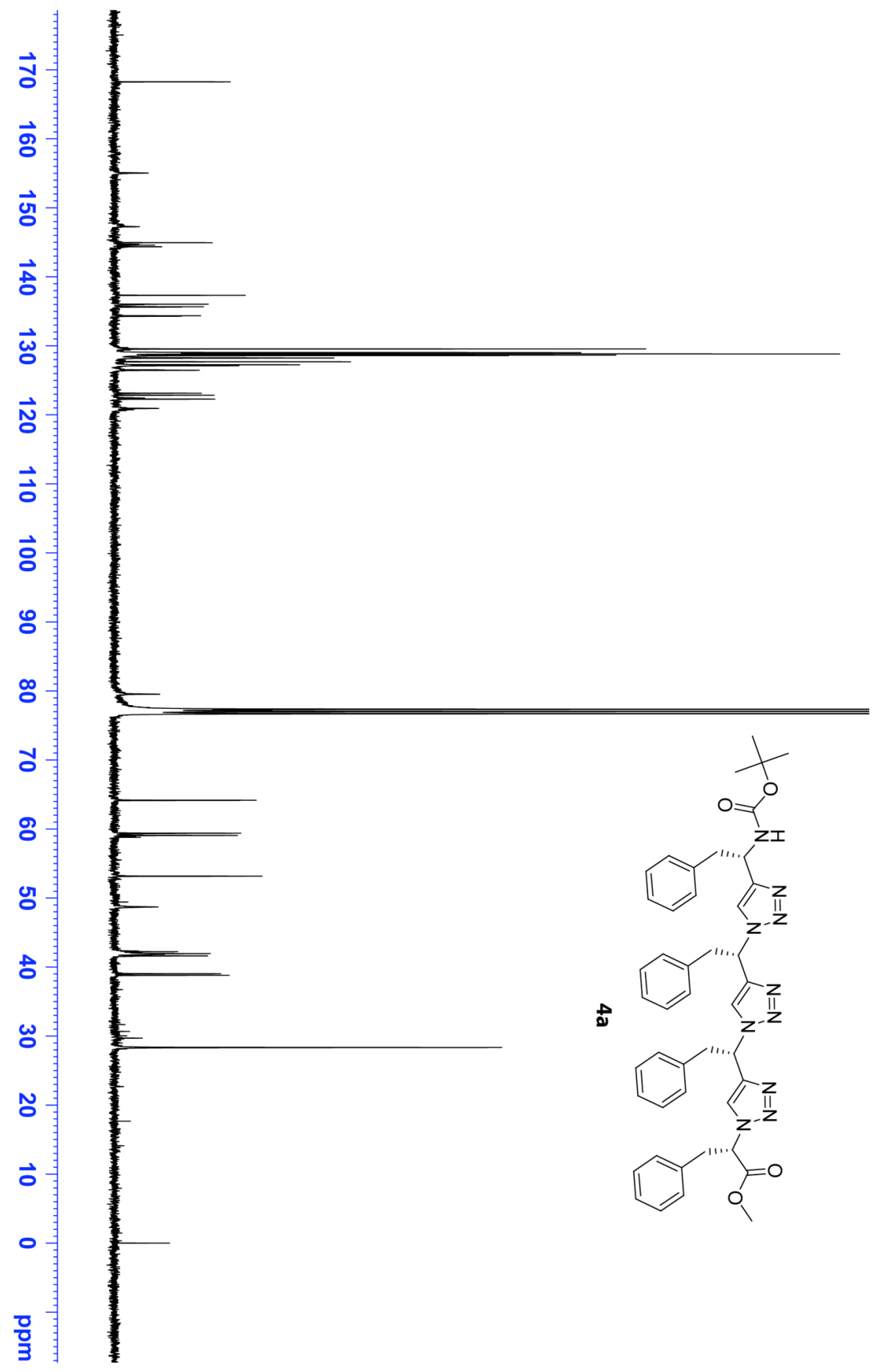


Angelo, et al.
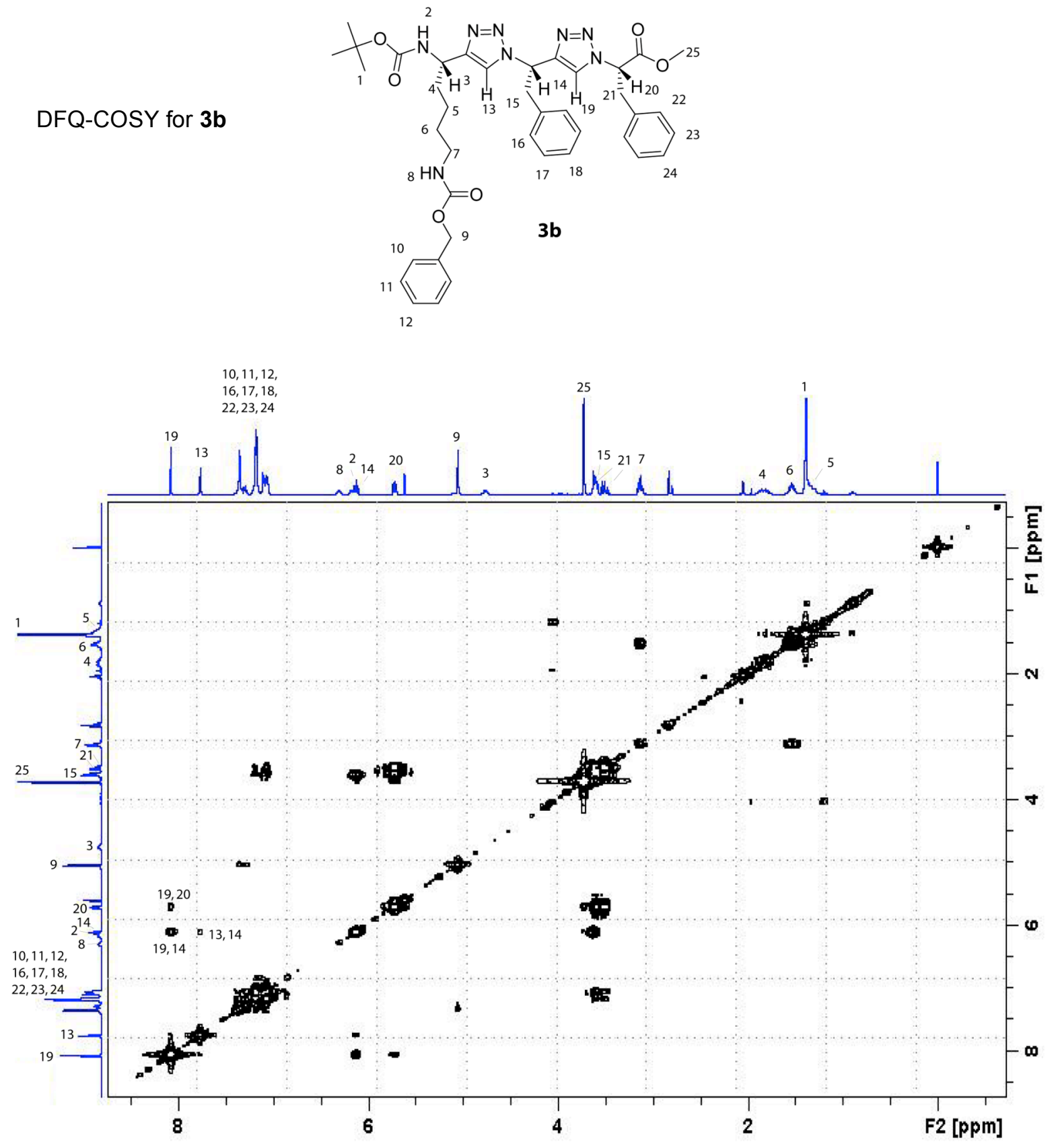
Angelo, et al.

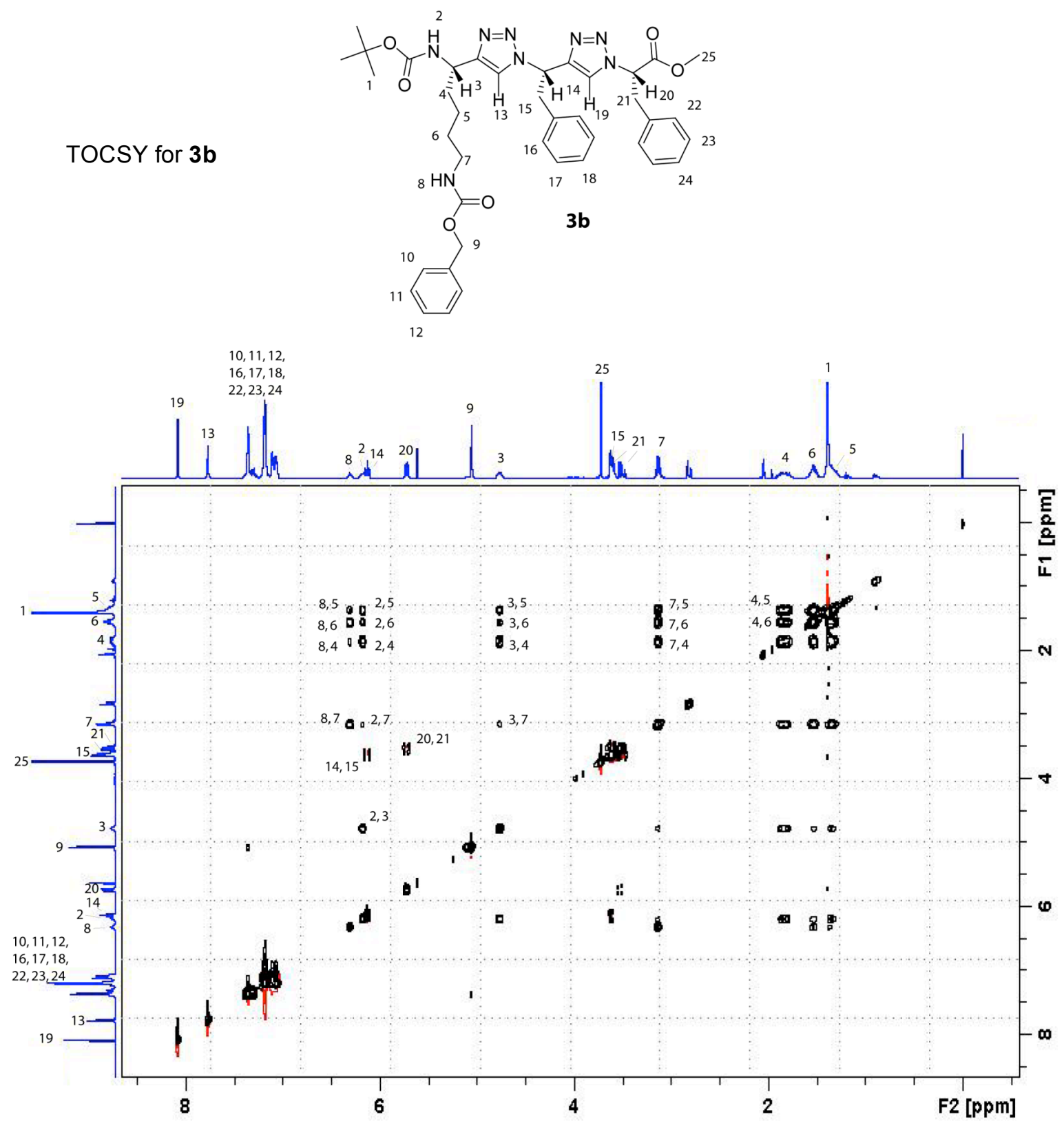


Angelo, et al.

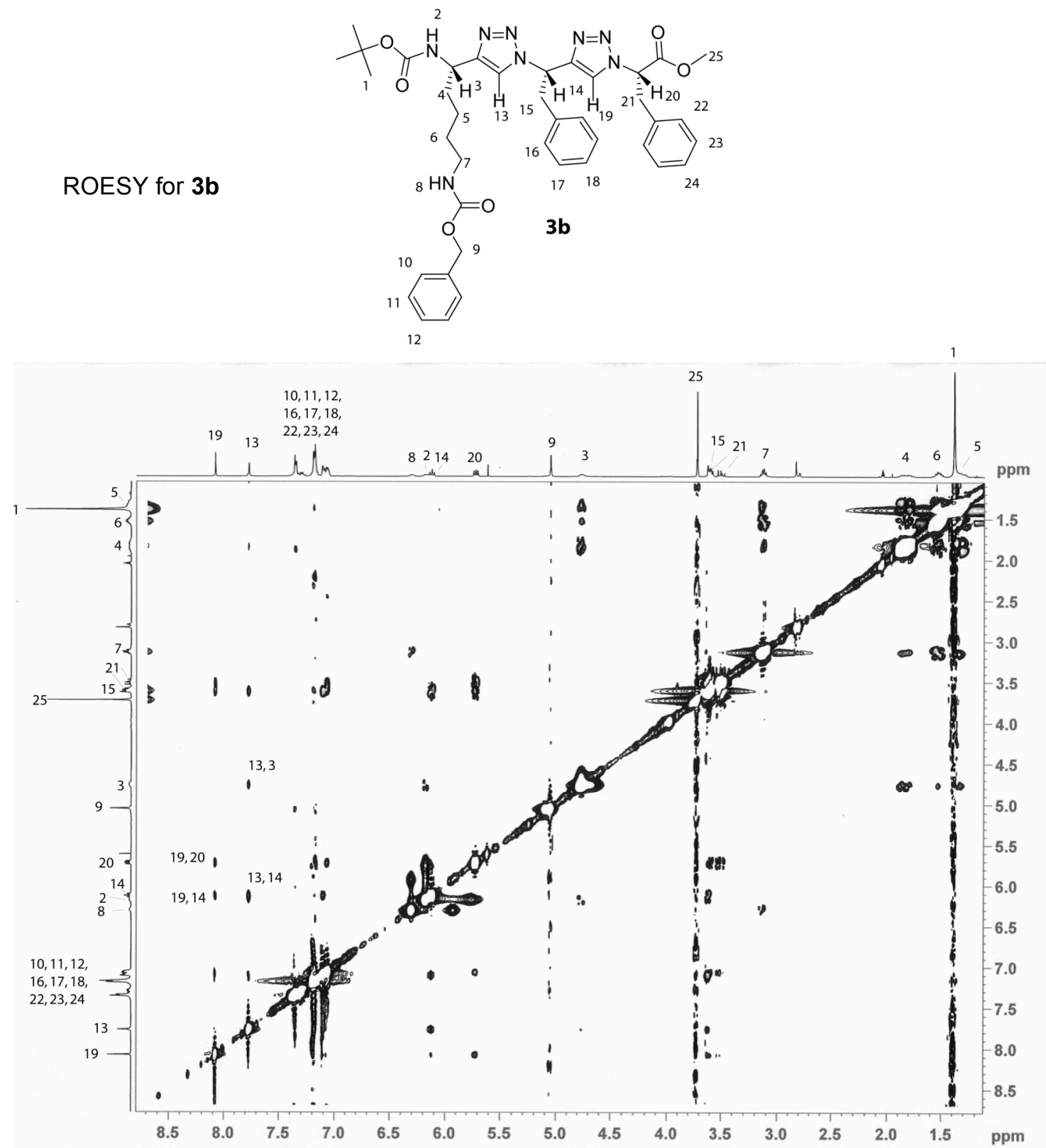


Angelo, et al.

${ }^{1} \mathrm{H}$ NMR for $\mathbf{3 b}$

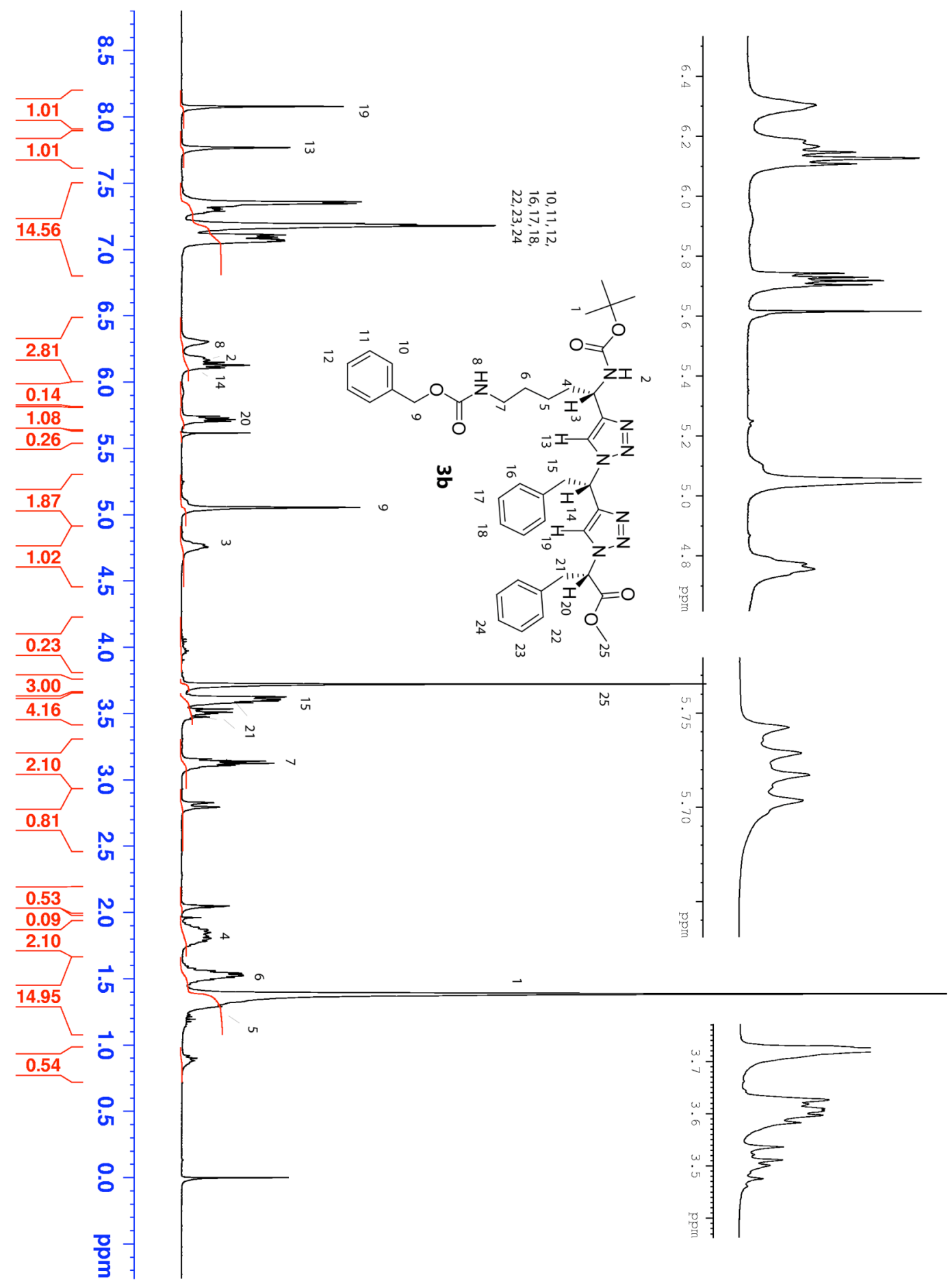


Angelo, et al.

${ }^{13} \mathrm{C}$ NMR for $3 \mathbf{b}$

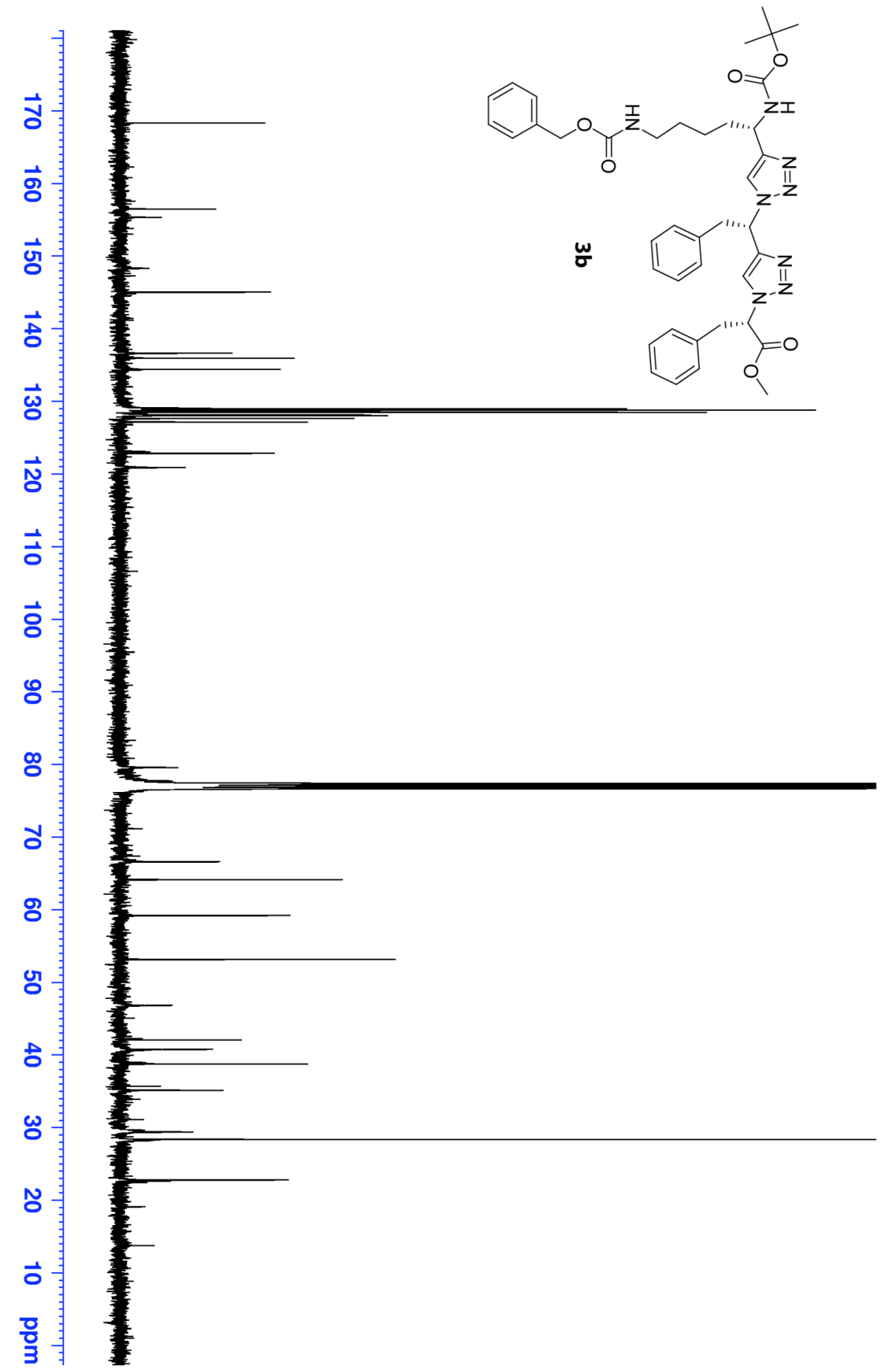


Angelo, et al.
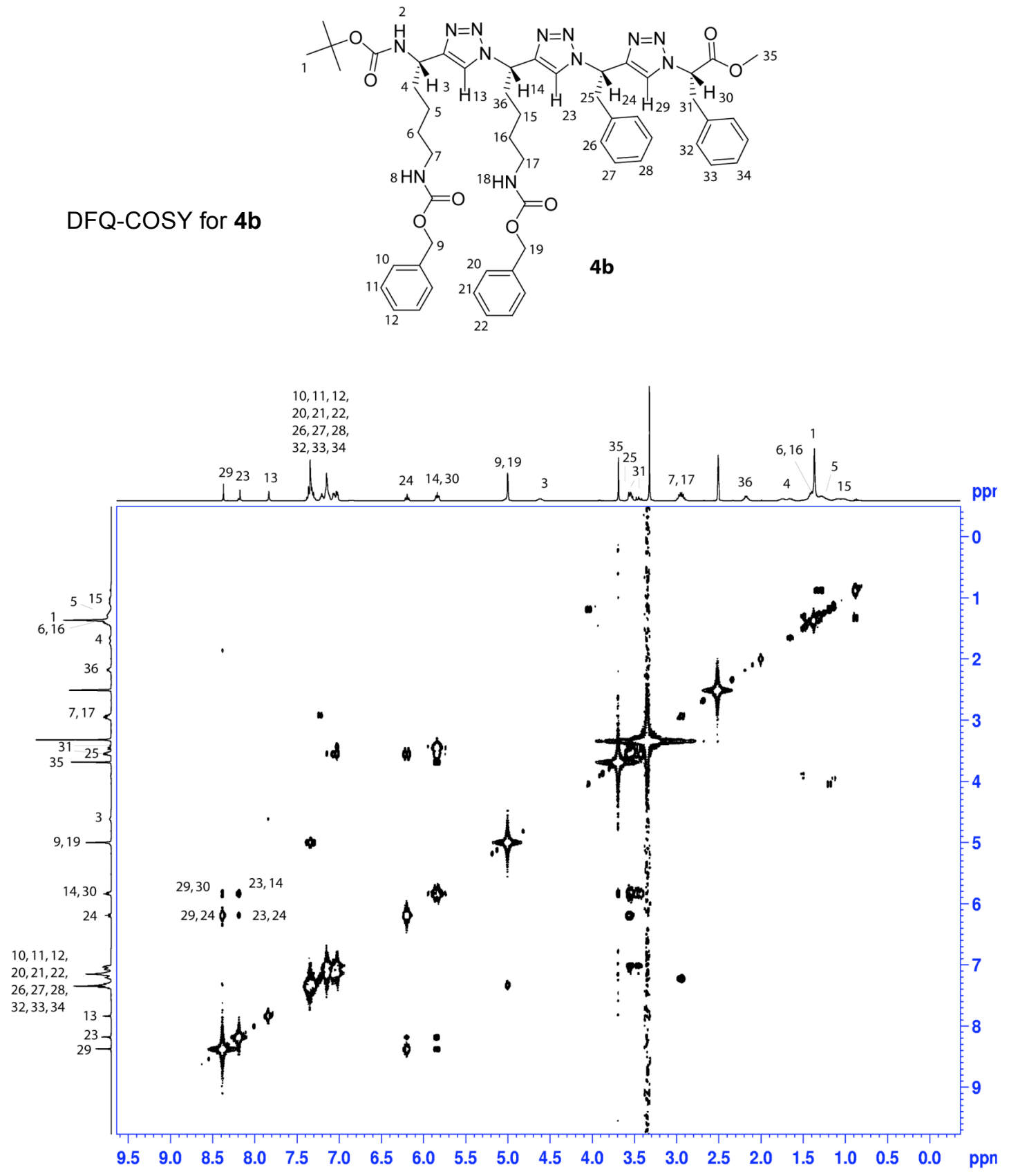
Angelo, et al.

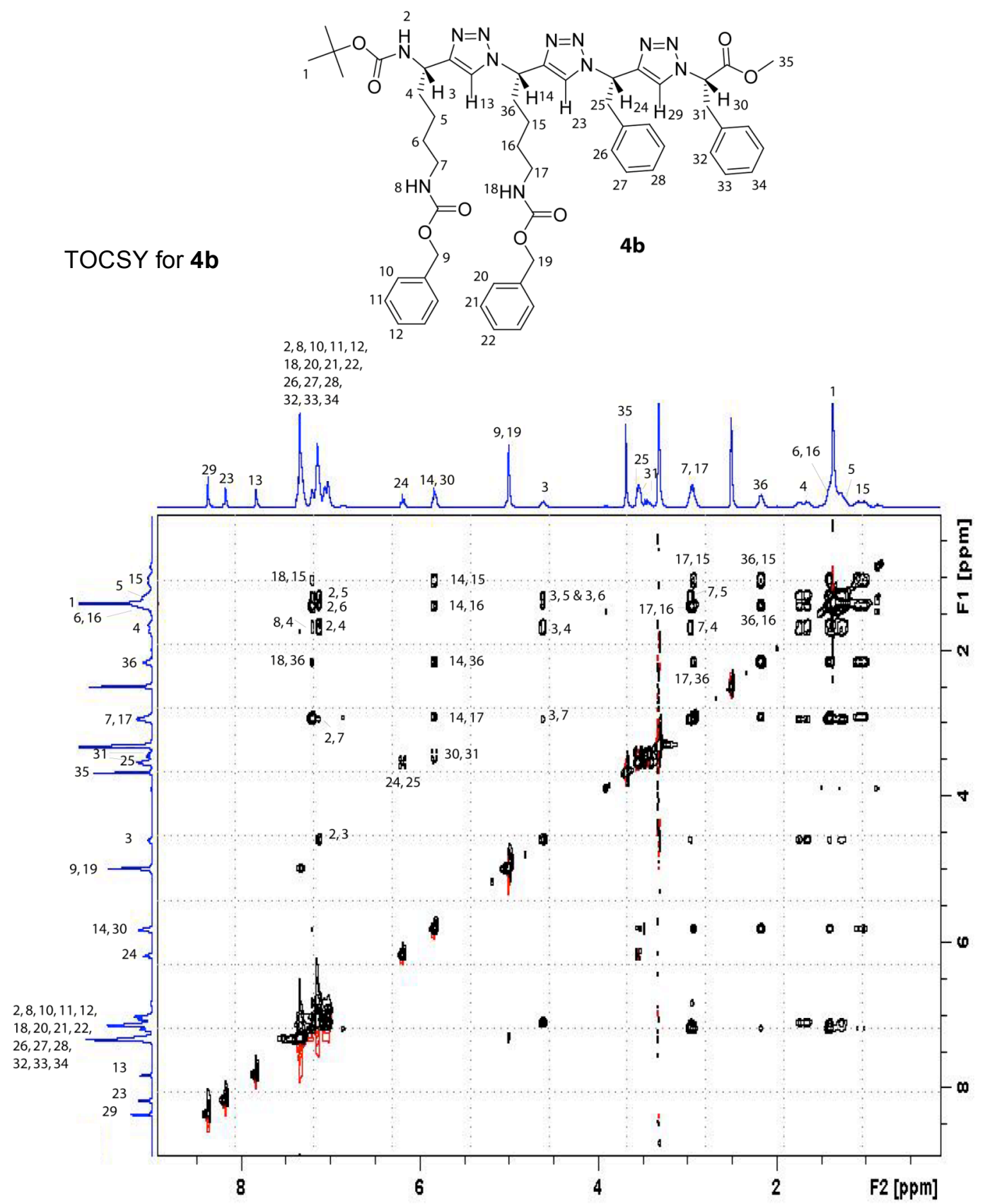


Angelo, et al.
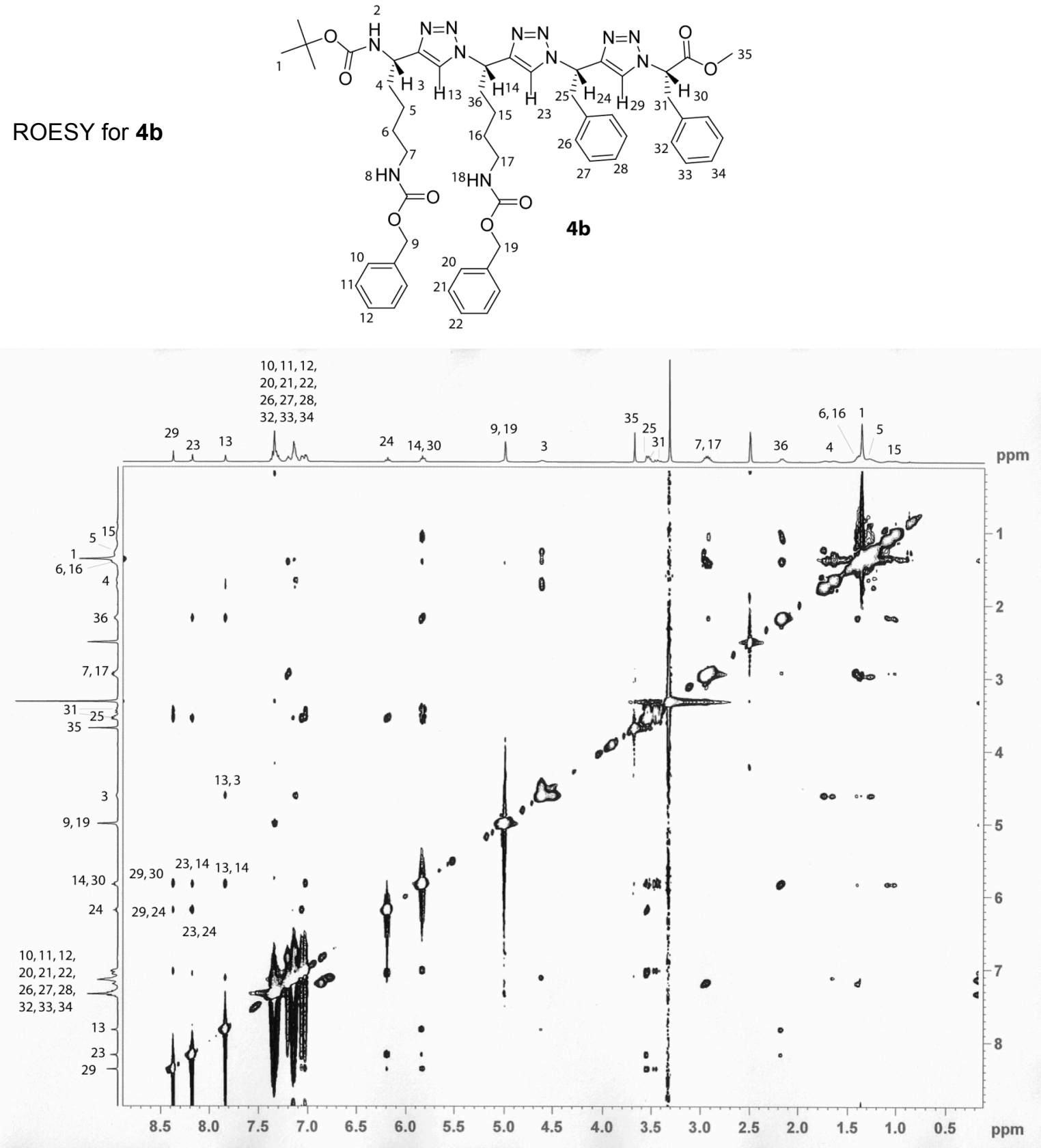
Angelo, et al.

\section{${ }^{7} \mathrm{H}$ NMR for $\mathbf{4 b}$}

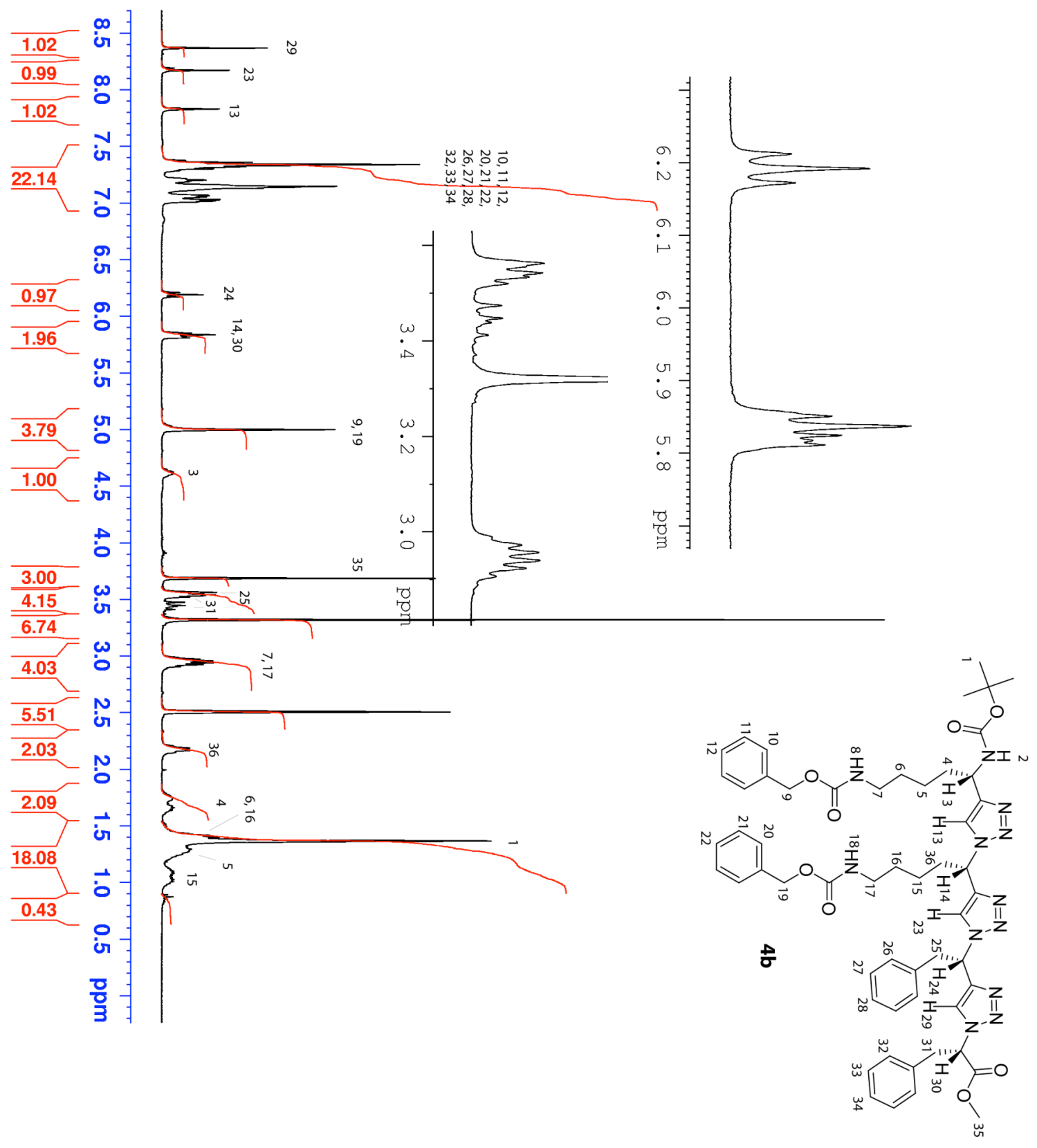


Angelo, et al.

${ }^{13} \mathrm{C}$ NMR for $\mathbf{4 b}$

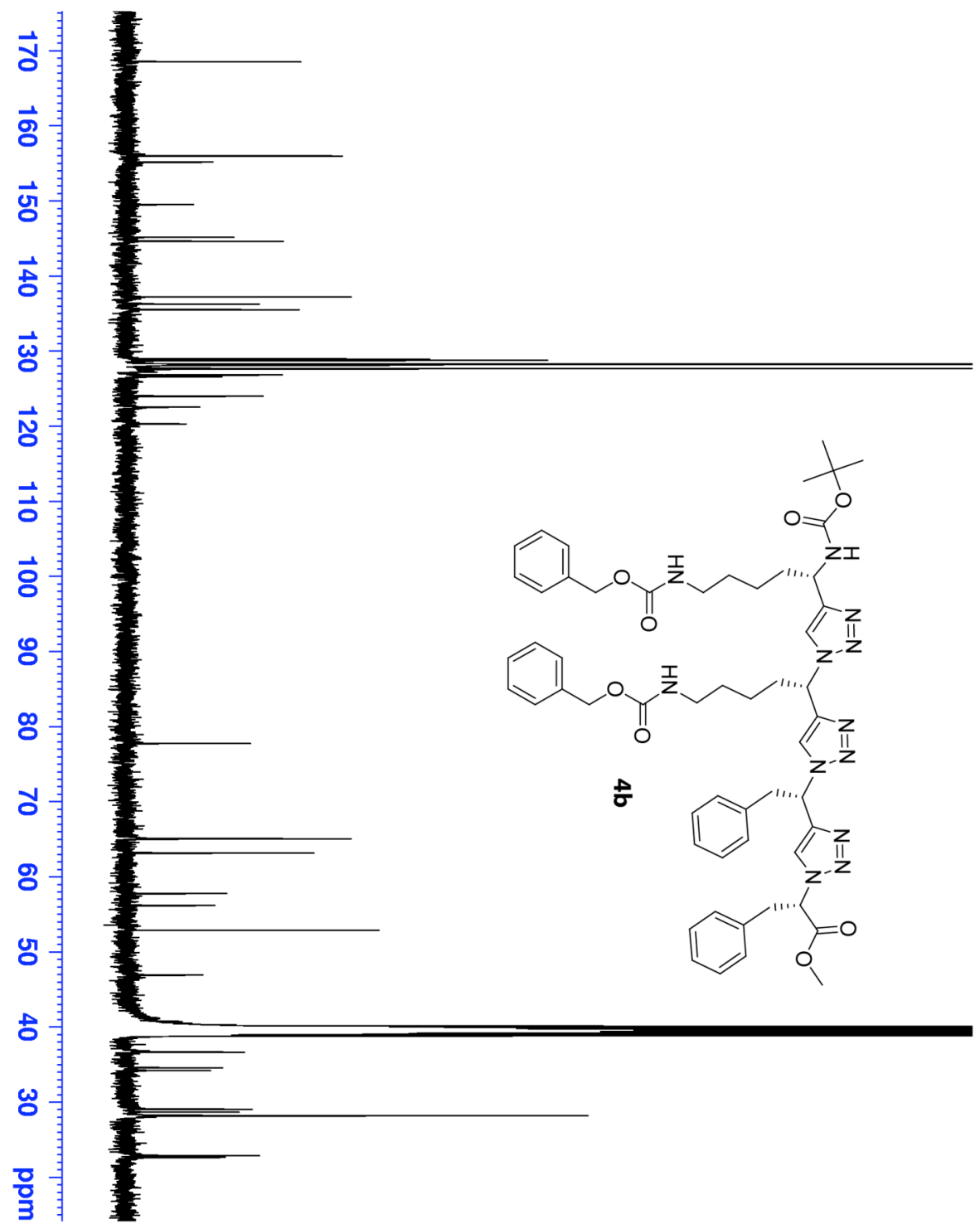

